\title{
Intersectionality as a Regulative Ideal
}

\author{
KATHERINE GASDAGLIS \\ California State Polytechnic University, Pomona \\ ALEX MADVA \\ California State Polytechnic University, Pomona
}

\begin{abstract}
What is the intersectional thesis a thesis about? Some understand it as a claim about the metaphysics of oppression, social kinds, or experience; about the limits of antidiscrimination law or identity politics; or about the importance of fuzzy sets and multifactor analysis in social science. We argue, however, that intersectionality, interpreted as a thesis in any particular theoretical domain, faces regress problems. We propose that headway on these and other questions can be made when intersectionality is modeled as a regulative ideal, i.e., a guiding methodological and practical principle, and not as a general theory or hypothesis. Qua ideal, intersectionality requires activists and inquirers to treat existing classification schemes as if they are indefinitely mutually informing, with the specific aim of revealing and resisting inequality and injustice. Qua regulative, intersectionality points to a rich and expanding set of heuristics for guiding social-scientific research and the construction of multifaceted political coalitions.
\end{abstract}

PPEALs to intersectionality serve to remind us that social categories like race
ond gender cannot be adequately understood independently from each
other. But what, exactly, is the intersectional thesis a thesis about? Answers to
this question are remarkably diverse. Intersectionality is variously understood
as a claim about the nature of social kinds, oppression, or experience (Cole 2009;
Collins 2003; Crenshaw 1989; 1991; Nash 2008; Shields 2008); about the limits of
antidiscrimination law or identity politics (Crenshaw 1989; 1991; 2008); or about
the importance of fuzzy sets (Hancock 2007b), multifactor analysis (Dubrow
2013; Else-Quest \& Hyde 2016; McCall 2005), or causal modeling (Bright, Malin-
sky, \& Thompson 2016) in social science.

Contact: Katherine Gasdaglis <klgasdaglis@cpp.edu> and Alex Madva <alexmadva@gmail.com> 
We worry, however, that interpreting intersectionality as a general hypothesis in any particular theoretical domain - be it social science, activism, law, or ontology-leads to regress problems (cf. Anthias 2009: 11; Butler 1999: 182-183; Carastathis 2014b: 3; Collins 2003: 203; K. Davis 2008: 77; Degraffenreid v. General Motors Assembly Div., Etc. 1976; Ehrenreich 2002; Puar 2007: 23-24; Táíwò 2018: 8; Young 1994: 718-721; Yuval-Davis 2006: 201-203). If social kinds are, at base, intersections of indefinitely many mutually-constituting factors, there is no inprinciple way to carve social reality at its constructed joints. There is, moreover, no a priori reason to privilege one of these groupings (or reference classes ${ }^{1}$ ) over another when making generalizations, or when forming political coalitions.

This essay argues that these problems dissolve when intersectionality is modeled as a regulative ideal, that is, a guiding methodological principle, rather than a general theory or hypothesis. Qua ideal, intersectionality requires activists and inquirers to treat existing classification schemes as if they are indefinitely mutually informing, with the specific aim of revealing and resisting inequality and injustice. Qua regulative, intersectionality points to a rich and expanding set of heuristics for guiding research in many fields and the construction of multifaceted political coalitions. On this account of intersectionality, the value of any particular social schema or category must be determined empirically and not a priori (see also, e.g., Cole 2009; Garry 2011; Hancock 2007a; 2007b; Haslanger 2014; May 2015; McCall 2005; Táíwò 2018).

At the outset, it bears emphasizing that our aim is not to supplant existing interpretations of intersectionality, but, first, to address head-on the regress concern about intersectionality that is often mentioned in passing but less often considered in depth, and, second, in addressing this concern, to further develop, integrate, and to some degree unify insights from the writings of numerous intersectional theorists. ${ }^{2}$ In particular, our view builds on a family of interpretations that view intersectionality as a method, mode, or way of engaging in social inquiry or political coalition building. We are especially inspired by those that describe intersectionality as an attention-guiding "heuristic device" (e.g., Anthias 1998; Bailey 2009; Cho, Crenshaw, \& McCall 2013; Clarke \& McCall 2013; Collins \& Bilge 2016; Garry 2011; MacKinnon 2013). Our interpretation analyzes intersectionality in terms of the ways we go about try-

1. Our focus in this paper will be on (what the intersectional literature frequently refers to as) "regress problems" that arise on certain interpretations of intersectionality, but a roughly analogous set of concerns arise for these interpretations in relation to the reference-class problem from statistics, which refers to the difficulty of identifying the appropriate class for estimating probabilities about particular cases (see, e.g., the hypothetical case of Reema in \$3.3).

2. We will say more about the potential payoffs and perils of purporting to offer a unified interpretation of intersectionality in $\S 5.4$ (see also $\S \S 2.4,2.5,5.2$, and 5.3 ). 
ing to interpret the world as well as the ways we go about trying to change it. Intersectionality as a regulative ideal is a principle for theoretically and practically engaging the social world. ${ }^{3}$

It also bears noting that, when it comes to theorizing about oppression, epistemic deference to members of oppressed communities is incredibly important (Schroer 2015; cf. Alcoff 1991). In light of this epistemic imperative, one might wonder why those interested in intersectionality don't simply defer to, for example, what preeminent black feminists have historically said about it. Indeed, while our account is rooted in close readings of black feminist scholarship, neither black feminism nor intersectional scholarship and activism are a monolith. Work on intersectionality is a tradition, and, like all traditions, it is internally diverse, vibrantly debated, and constantly evolving. (One might just as well ask why psychologists, politicians, and physicists don't defer to what "philosophers" say about consciousness, justice, or free will! The question immediately arises: which "philosophers"?)

In fact, leading intersectional theorists have continued to interrogate and reinterpret intersectionality. For example, Patricia Hill Collins shares the following course description from her syllabus for a 2012 graduate seminar on intersectionality:

What exactly is intersectionality? Is it a concept, a paradigm, a heuristic device, a methodology, or a theory? If it is a theory, what kind of theory is it? Because intersectionality constitutes a new term applied to a diverse set of practices, interpretations, methodologies and political orientations, we cannot assume that we are studying a fixed body of knowledge. Instead, our course will investigate the question of the interpretive frames of intersectionality itself. (2015:2)

She explains, however, that, "Despite our best efforts, by the end of the course my students and I both seemed stuck in [Supreme Court Justice Potter] Stewart's dilemma - we thought we 'knew' intersectionality when we saw it but couldn't quite define what it was" (Collins 2015: 2). We aim to contribute to these ongoing, collaborative efforts, and follow Collins in describing her own interest in defining intersectionality: "I am not trying to prematurely tame intersectionality's unruliness by imposing an imperial definition from above. Definitions constitute

3. Taxonomies of intersectionality often distinguish its practical application in the context of activism and coalition-building from its theoretical, methodological, or analytical applications. This way of taxonomizing is useful for both philosophical and social-scientific studies of intersectionality. However, modeling intersectionality as a regulative ideal, i.e., as a principle for how to engage intersectional projects, reveals how these disparate domains of activity are, despite their real differences, nevertheless, in a key sense instantiations of a more general approach. 
starting points for investigation rather than end points of analysis" (Collins 2015: 3). Minimally, we hope to show that the concept of a regulative ideal represents a useful resource for advancing intersectional thought and action.

We begin $(\S 1)$ by describing what we take to be paradigmatic examples that motivate an intersectional approach. We then (\$2) briefly summarize several leading interpretations of intersectionality and argue $\left(\S_{3}\right)$ that these interpretations face potentially vicious regress problems. We suggest that methodological interpretations of intersectionality are the most promising way to avoid these pitfalls (§4), but that what, if anything, unifies the proposed interpretations of intersectionality remains unclear. We then $(\$ 5)$ articulate and defend our view of intersectionality as a kind of regulative ideal, showing how this model avoids the vicious regress and offers some unity to existing interpretations. We conclude with two case studies-one drawn from social science and the other from intersectional activism-illustrating how the ideal applies in practice.

\section{Motivating Intersectionality}

Building on decades of pathbreaking work in black feminism, ${ }^{4}$ Kimberlé Crenshaw (1989) writes that,

dominant conceptions of discrimination condition us to think about subordination as disadvantage occurring along a single categorical axis ... this single-axis framework erases black women in the conceptualization, identification and remediation of race and sex discrimination by limiting inquiry to the experiences of otherwise-privileged members of the group. (1989: 140)

Sexism, she argues, is often implicitly modeled as discrimination against white women, while racism is implicitly modeled as discrimination against black men. The result is that the distinctive forms of sexism and racism experienced by black women go unidentified and misunderstood (i.e., a hermeneutical injustice; Dot-

4. Although Crenshaw did not use the label "intersectionality" until 1989, feminists of color had begun approaching social reality in intersectional terms much earlier. For historical overviews, see, e.g., Brah and Phoenix (2013), Collins (2015: 7-11), Collins and Bilge (2016: Chapter 3), Hancock (2016), and May (2015: Chapter 1). These and other writers explore precursors to intersectionality in $19^{\text {th }}$ - and early $20^{\text {th }}$-century black feminists including Sojourner Truth, Anna Julia Cooper, Maria Stewart, and Mary Church Terrell. In 1892, for example, Cooper wrote, "The colored woman of to-day occupies, one may say, a unique position in this country. In a period of itself transitional and unsettled, her status seems one of the least ascertainable and definitive of all the forces which make for our civilization. She is confronted by both a woman question and a race problem, and is as yet an unknown or an unacknowledged factor in both" (Cooper 2017: 76/134). 
son 2014; Fricker 2007), which, in turn, makes redressing these wrongs difficult or impossible.

In the $20^{\text {th }}$-century, for example, black feminists like Angela Davis (1983) and bell hooks (1984) argue that framing gender discrimination in terms of trapping women in domestic life and barring them from the workplace only makes sense when our attention is trained on women who are white, married, and comparatively wealthy. These claims about "women" make no sense when we think about the historical and ongoing injustices suffered by women of color (see also Du Bois 1920: Chapter 7). Responding to Betty Friedan's The Feminine Mystique, hooks writes:

Friedan concludes her first chapter by stating: "We can no longer ignore that voice within women that says: 'I want something more than my husband and my children and my house."' That "more" she defined as careers. She did not discuss who would be called in to take care of the children and maintain the home if more women like herself were freed from their house labor and given equal access with white men to the professions. She did not speak of the needs of women without men, without children, without homes. She ignored the existence of all non-white women and poor white women....

She made her plight and the plight of white women like herself synonymous with a condition affecting all American women. In so doing, she deflected attention away from her classism, her racism, her sexist attitudes toward the masses of American women ... Specific problems and dilemmas of leisure-class white housewives were real concerns that merited consideration and change, but they were not the pressing political concerns of masses of women. Masses of women were concerned about economic survival, ethnic and racial discrimination, etc. When Friedan wrote The Feminine Mystique, more than one-third of all women were in the work force. (hooks 1984: 1-2)

Thus, in volumes such as But Some of Us Are Brave: All the Women Are White, All the Blacks Are Men (Hull, Bell-Scott, \& Smith 1993), black feminists argue that the distinctive forms of discrimination they experience are either entirely overlooked, or, when addressed, wrongly modeled as an additive sum of racism and sexism. Against this trend, they argue that "the major systems of oppression are interlocking. The synthesis of these oppressions creates the conditions of our lives" (Combahee River Collective 1977). It is not just that they have quantitatively greater hurdles to overcome than white women or black men, but that the nature of their oppression reflects a distinctive, complex, and perhaps irreducible combination of sexism, racism, and other structures of oppression, such as 
classism and heterosexism. As Ann Garry later puts it, on an intersectional approach, "each kind of oppression or privilege is shaped by and works through the others" (Garry 2011: 496).

How does this view depart from more traditional approaches? According to traditional "additive" understandings of racism and sexism, by contrast, there is a certain set or quantity of disadvantages to which individuals are subject in virtue of being black, and a set or quantity of disadvantages to which individuals are subject in virtue of being women. The union or sum of these disadvantages would be roughly equivalent to the disadvantages to which individuals would be subject in virtue of being black women. There are some contexts in which this additive approach appears, very roughly, to capture the phenomena. For example, one study found that members of multiple disadvantaged social groups (in this case, low-income women of color) were more affected by stereotype threat than members of just one or two disadvantaged groups (Tine \& Gotlieb 2013); another found that black women were more likely to experience incivility and testimonial injustices in the workplace than white women and black men (Cortina, Kabat-Farr, Leskinen, Huerta, \& Magley 2013; see also Branco, Ramos, \& Hewstone 2019). Consider also average pay gaps associated with race, ethnicity, and gender. If one were just to eyeball a chart showing average wages over time, ${ }^{5}$ one would see that white men earn more than white women, and more than black and Latino men, whereas these latter groups in turn earn more than black women and Latina women. ${ }^{6}$

However, despite superficial appearances, the data on pay gaps don't approximate an additive account (Greenman \& Xie 2008; Misra \& Murray-Close 2014). Specifically, the gender pay gap is larger between white men and white women than it is between men and women of other groups, and the racial pay gap is larger among men than it is among women. When it comes to wages, white men benefit more from male privilege than do men of color, and they benefit more from white privilege than do white women, evidently in large part because white couples remain more likely to adopt patriarchal gender roles,

5. This table is drawn from https://www.infoplease.com/us/wage-gap/wage-gap-genderand-race, which is based on the U.S. Current Population Survey and the National Committee on Pay Equity, and the Bureau of Labor Statistics: Weekly and Hourly Earnings Data from the Current Population Survey.

6. Do other groups, such as Asian-American men and women, also suffer from a pay gap? It is increasingly claimed that Asian-Americans now out-earn their white counterparts, but this is misleading and intersectional inquiry reveals how. Controlling for factors including geography (e.g., cost of living in areas with larger concentrations of people of Asian descent, namely, California and New York) and occupation, then the apparent "bonuses" for Asian-American workers disappear (e.g., Kim \& Zhao 2014). Moreover, although Asian-American employment rates are comparatively high, Asian-American employees are less likely to be promoted to managerial positions due to stereotypes about their perceived lack of social skills. 
Table 1. Wage Gap by Race and Gender in the United States from 1970 to 2013

\begin{tabular}{lllcccc}
\hline Year & $\begin{array}{c}\text { White } \\
\text { men }\end{array}$ & $\begin{array}{c}\text { Black } \\
\text { men }\end{array}$ & $\begin{array}{c}\text { Hispanic } \\
\text { men }\end{array}$ & $\begin{array}{c}\text { White } \\
\text { women }\end{array}$ & $\begin{array}{c}\text { Black } \\
\text { women }\end{array}$ & $\begin{array}{c}\text { Hispanic } \\
\text { women }\end{array}$ \\
\hline 1970 & $100 \%$ & $69.0 \%$ & n.a. & $58.7 \%$ & $48.2 \%$ & n.a. \\
1975 & 100 & 74.3 & $72.1 \%$ & 57.5 & 55.4 & $49.3 \%$ \\
1990 & 100 & 73.1 & 66.3 & 69.4 & 62.5 & 54.3 \\
2000 & 100 & 78.2 & 63.4 & 72.2 & 64.6 & 52.8 \\
2013 & 100 & 75.1 & 67.2 & 78 & 64 & 54 \\
\hline
\end{tabular}

such that white married mothers in comparatively advantaged socioeconomic circumstances work outside the home less than nonwhite married women (e.g., Parrott 2014). In this case, the socioeconomic advantages for members of multiple privileged groups (e.g., white men) are more than the sum of the advantages that male privilege confers on men of color and that white privilege confers on white women. Nawyn and Gjokaj refer to this as a magnifying effect of privilege, such that "one privileged status magnifies the positive economic outcomes of other privilege statuses" (2014: 86). Ultimately, Greenman and Xie conclude that, "among U.S. workers, there is no such thing as a pure 'gender effect' or 'race effect' when it comes to earnings. The two must be considered simultaneously" (Greenman \& Xie 2008: 20). Such claims about the necessity of analyzing categories like race and gender simultaneously are paradigmatic of intersectionality (more specifically, they are paradigmatic of quantitative intersectional social science).

In a further range of contexts, the disadvantages facing members of multiple oppressed groups are qualitatively different-of a different character altogether-from those faced by members of just one oppressed group. For example, consider Crenshaw's (1991: 1245-1250) discussion of the unique wrongs suffered by undocumented women in the United States who face domestic violence. Undocumented women are deterred from reporting domestic violence to the police, for fear of deportation from the very authorities from whom they might seek help. Undocumented women have also faced additional structural barriers in seeking other forms of assistance, including, for example, shelter regulations that required women to speak English in order to participate in talk therapies (Crenshaw 1991: 1262-1265). Such oppressive conditions are specific to the social locations of these women and are, in certain important respects, different in kind from the conditions of both undocumented men and documented women. In these and other cases, the failure to adopt an intersectional approach leads to the political, empirical, and even social-cognitive erasure or "invisibility" of the experiences and injustices faced by members of multiple disadvantaged groups (Purdie-Vaughns \& Eibach 2008; Schug, Alt, Lu, Gosin, \& Fay 2017; Sesko \& Biernat 2010). 
Yet some of the most striking evidence against the adequacy of the additive approach consists in surprising findings that, in certain contexts, members of multiple oppressed groups have relative advantages over members of singly oppressed groups (e.g., King 1988: 46-51). For example, one experiment asked participants to evaluate and recommend a starting salary for one of four possible applications for Assistant Manager at a retail store (Pedulla 2014; see also Petsko \& Bodenhausen 2019; Wilson, Remedios, \& Rule 2017). The applications varied by both race ("Brad Miller" or "Darnell Jackson") and sexuality ("President of the Student Advisory Council" or "President of the Gay Student Advisory Council"). Participants recommended a higher starting salary for the straight white man over both the straight black man and the gay white man-but not over the gay black man. In this specific study, there was no disadvantage for the gay black applicant relative to the straight white applicant; discrimination related to race and sexuality somehow "canceled out."7 Similarly, evidence suggests that, relative to white men, both white women and black men are penalized for adopting a "dominant" rather than a "communal" leadership style (e.g., for saying "I demand that you take steps to improve your performance" rather than "I encourage ..."); in some contexts, however, black women leaders suffer no such dominance penalty (Livingston, Rosette, \& Washington 2012; see also Harkness 2016; Chetty, Hendren, Jones, \& Porter 2018). The flip side of this ostensible (context-specific) black-womanhood advantage is that black women leaders are instead penalized when they fail to be sufficiently agentic and appear too nurturing (Rosette, Koval, Ma, \& Livingston 2016; see also Settles 2006). ${ }^{8}$ Occupying a multiply disadvantaged social location - or, for that matter, occupying any social location-generates a contextually variable mix of both "constraints and freedoms" (Harkness 2016: 83).

The foregoing examples represent nothing like a comprehensive survey of the breadth and depth of intersectionality. In particular, our examples predominantly draw from quantitative social science, which by no means exhausts intersectionality's empirical or sociopolitical relevance. ${ }^{9}$ Nevertheless, we take these examples to highlight the inadequacy of single-factor, additive, or otherwise simplistic approaches to social reality, stereotyping, discrimination, power, and oppression. They suffice to make the need for an intersectional approach clear.

7. We circle back to this study in $\$ 5.5$.

8. "Simply stated, Black women are perceived as being dominant but not competent. Asian American women are perceived as being competent but passive. White women are perceived as primarily communal without being seen as particularly dominant or excessively competent. Consequently, Black women are the least likely to suffer agentic penalties, whereas Asian American women (and perhaps to a lesser degree White women) are most likely to suffer agentic penalties. The pattern is reversed for agentic deficiencies" (Rosette, Koval, Ma, \& Livingston 2016: 12).

9. Book-length treatments of intersectionality offer a wider range of cases (e.g., Collins \& Bilge 2016; Hancock 2016; May 2015). 
But what exactly is intersectionality? We next review several of the most prominent characterizations of the concept.

\section{Interpreting Intersectionality}

Despite being indispensable for social theory and activism, intersectionality has-like so many philosophically important ideas-eluded precise definition (Collins 2015). It has been interpreted and taxonomized in numerous ways, sometimes being explicitly defined in different ways within the same paper. In what follows we summarize several leading treatments.

\subsection{Intersectionality as a Piece of Social Metaphysics or Social Science}

Intersectionality is frequently glossed as a metaphysical claim about the mutual construction of certain social phenomena. We'll call this the metaphysical coconstitution thesis. Precisely which entities are said to be co-constituting varies. The co-constitution thesis is often applied to social identities or categories (e.g., being a woman and being black), and to social structures and systems (the positioning and treatment of individuals and groups in a broader network of social relations). For example, Stephanie Shields defines intersectionality as "the mutually constitutive relations among social identities" (2008: 301), and Jennifer Nash asks if it provides "a general theory of identity" (2008: 10). ${ }^{10}$ As Elizabeth Spelman puts it, we must reject the notion that:

a woman's identity consists of a sum of parts neatly divisible from one another, parts defined in terms of her race, gender, class, and so on ... . and that in her various political activities she works clearly now out of one part of herself, now out of another. (Spelman 1988: 136)

Spelman's point is that it is a mistake to think that a person may tease apart the different strands that constitute the complex yarn of her self-conception, as if, now, she identifies as a woman, later as black, and later still as gay. It is not just that a person may be all of these things together, but also that, in attempting to tease them apart, we obscure the ways they mutually constitute one another. ${ }^{11}$

Such claims about intersectional co-constitution are frequently made at the level of social metaphysics, that is, about the nature of identities, categories, or

10. Crenshaw also refers to "intersectional identities such as women of color" (Crenshaw 1991: 1243).

11. On the metaphor of sex, gender, and sexuality as intersecting like yarn (where "yarn" is intended to invoke both thread and narrative), see Jordan-Young (2011: 12-18). 
structures. This construal of intersectionality is also adopted by social scientists (in sociology, political science, psychology, economics, etc.). ${ }^{12}$ Given that these categories are deemed to be co-constituting, intersectional social scientists further conclude that the categories cannot be studied, theorized, or generalizedabout independently, as when Greenman and Xie state that there is no "pure" race or gender effect on earnings.

Claims about co-constitution reappear in other leading glosses of intersectionality as well-as when intersectionality is defined as part of a political theory of oppression, that is, as a normative concept for capturing certain forms of injustice. In this context, intersectionality is seen as more about the natures of racism and sexism than about race and gender.

\subsection{Normative Co-Constitution and Structural Oppression}

Many accounts of intersectionality treat it as a reminder to conceptualize sexism, racism, and other forms of oppression in terms of unjust social structures. In Crenshaw's example (\$1), the structural forces operating on undocumented, non-native-English-speaking women suffering from domestic violence are different in kind from those faced by documented women and American citizens. The Combahee River Collective coined the phrase "interlocking systems of oppression" to characterize such phenomena, while Collins (1990) refers to the "matrix of domination," and Crenshaw (1991) to "structural intersectionality." On these interpretations, intersectionality is a way of identifying the multiply disadvantaging dimensions of laws, institutions, and norms. ${ }^{13}$ In this vein, Crenshaw (1989) focused on the inadequacies of existing law and judicial precedent for "the conceptualization, identification and remediation of race and sex discrimination" (1989: 140).

The normative-structural approach to intersectionality has also been used to criticize the marginalizing tendencies embedded within the leadership structures and priority-setting mechanisms of traditional social-justice movements, political discourses, and identity politics. Termed "political intersectionality" by Crenshaw, the claim here is that the political interests of women of color "tend not to be represented within the discourses of either feminism or antiracism" (Crenshaw 1991: 1243-1244; see also 2008; and King 1988), which have historically focused instead on advancing the interests of white women and black men, respectively. Political intersectionality points to a failure on the part of those at-

12. See, e.g., the scientists cited in $\S 1$.

13. Structures also include, e.g., the layouts of physical spaces, exposure to food deserts, exposure to environmental toxins, etc. See also Deborah King's claim that, "racism, sexism, and classism constitute three, interdependent control systems" (1988: 47). 
tempting to change social reality to acknowledge and prioritize the interests of those who live on the margins.

\subsection{Epistemology and Experience}

Claims about social identity and structural oppression are also connected to epistemic, phenomenological, and psychological interpretations of intersectionality, which refer to the experience and knowledge of members of multiple disadvantaged groups. For example, Collins refers to "race, class, gender, sexuality, and national belonging as mutually constructing categories of experience" (2003: 209), and Crenshaw refers to "intersectional experiences" (1991: 1244). Here the idea is that what it's like to be, for example, a woman and black cannot be neatly articulated in terms of this or that single-factor social grouping (Barvosa 2008). Such experiential claims are, in turn, related to epistemic interpretations of intersectionality, which enrich and complicate feminist epistemological traditions such as standpoint theory (Collins 1990; Grasswick 2018). The insight here is that the distinctive experiences of individuals who occupy multiply disadvantaged social positions give them privileged epistemic access to certain regions of social reality.

There are various ways of drawing the different interpretations of intersectionality discussed in \$2.1 to §2.3 together. For example, Crenshaw argues that individuals' intersectional experiences reflect their corresponding normativestructural intersectional oppression. She writes that "the experiences of women of color are frequently the product of intersecting patterns of racism and sexism" (Crenshaw 1991: 1243; see also Else-Quest \& Hyde 2016: 319). And Collins (2003: 207) writes that, "Race, class, gender, and other markers of power intersect to produce social institutions that, in turn, construct groups that become defined by these characteristics." Intuitively, our personalized social identities, group affiliations, and experiences are shaped (at least in part) by broader social structures. If the systems of oppression are fundamentally intertwined, then, one might think, so too will be people's experiences of discrimination - and their understandings of what it means to inhabit various social identities. The intersection of structural inequalities will shape the psychological identities and experiences of individuals who occupy those intersections (and individuals who occupy different intersections). This then in turn explains why multiply marginalized individuals may have distinctive epistemic windows onto oppression.

\subsection{Buzzword?}

Yet given the diverse array of interpretations of intersectionality, some have grown skeptical of defining it at all. Davis (2008) argues that intersectionality 
is a "buzzword," akin to a viral meme glommed onto by social-justice activists, and largely devoid of substantive theoretical content (cf. Hancock 2016: Chapter 1; Knapp 2005: 254-255). Building on a footnote from Crenshaw (1991: Note 9), Carastathis (2014a: 60) suggests that intersectionality is an irredeemably "provisional" or "transitional" concept, on the way toward a richer theory of social identity, structure, and justice. Similarly, Phoenix and Pattynama (2006: 187) claim that intersectionality is "useful as a handy catchall phrase that aims to make visible the multiple positioning that constitutes everyday life and the power relations that are central to it."

\subsection{A Commitment to Focusing on Women of Color?}

Others object to the "traveling" of intersectionality beyond its roots in black feminism. In response to the viral-buzzword status of intersectionality and its application across a widening range of (sometimes depoliticized, mainstreamed, and institutionalized) contexts, some argue that intersectionality is, or should be, specifically about women of color. Thus Nikol Alexander-Floyd defines intersectionality as,

the commitment to centering research and analysis on the lived experiences of women of color for the purpose of making visible and addressing their marginalization as well as an ethos of challenging business as usual in mainstream disciplines' habits of knowledge production. (2012: 9; see also Bilge 2013; Jordan-Zachery 2013) ${ }^{14}$

We'd like to echo Alexander-Floyd's commitment to grounding intersectionality in the experiences of women of color, which is to say, in its ongoing living history. Any intersectional inquiry that is oblivious to its history and original aims risks the very erasure intersectionality means to resist. And we must, as Alexander-Floyd suggests, center our research and activist efforts on demarginalizing women of color. Yet we believe that intersectionality has much to teach and that its full epistemological import extends to a plurality of marginalizations (cf. Cho 2013; Táíwò 2018). The lessons to be learned from intersectionality must be historically grounded in the experiences of black women, but they are instructive for theorists interested in social reality and power in all of its

14. Some of Alexander-Floyd's claims (such as the one cited here) cast intersectionality as about women of color in general, whereas others cast it as specifically about black women (e.g., 2012: 9; see also next note). See also Puar's (2012) concerns about reification and other discursive and political consequences that might arise from centering intersectionality on American black women. 
detail. For example, we find evidence for ways of approaching social reality intersectionally that do not speak directly about women of color, such as Pedulla's (2014) study of the intersection of race and sexuality in discrimination against different groups of men.

Intersectional thought reveals that we are all members of multiple social categories and that everyone exists within a network of relations of privileges and oppressions. For this reason, we believe that intersectionality is essential for inquiring into any dimension of social reality, including the positioning and experiences of members of multiply advantaged groups. White privilege, for example, is different for white men and white women, for rich whites and poor whites, and so on. Similarly, male privilege is different for cis men and trans men, for straight men and gay men, for white men and black men. It is intersectionality that teaches us these lessons. With these many lessons in mind, our model aims to respect intersectionality's breadth as well. ${ }^{15}$

We are also moved by Jennifer Nash's caution against treating intersectionality as coextensive with all research by or about black women:

it is crucial to push against the notion that the work of black feminist theory has always been to consider the interlocking nature of structures of domination. This view can elide black feminist scholarship on love, desire, eroticism, pleasure, mourning, grief, corporeality, self-making, to name just a few of the myriad questions black feminists have considered, ignoring the myriad moments when black feminists have turned their critical attention toward theoretical and political questions removed from the interlocking nature of race and gender. (Nash 2017: 126)

15. For historical context, Deborah King (1988: 43 emphasis added) writes, "In addressing the National Association for the Advancement of Colored People (NAACP) Legal Defense Fund in 1971, Fannie Lou Hamer, the daughter of sharecroppers and a civil rights activist in Mississippi, commented on the special plight and role of black women over 350 years: 'You know I work for the liberation of all people because when I liberate myself, I'm liberating other people ... her [the white woman's] freedom is shackled in chains to mine, and she realizes for the first time that she is not free until I am free.' The necessity of addressing all oppressions is one of the hallmarks of black feminist thought."

Recall also Nawyn and Gjokaj's (2014) argument that there is a magnifying effect of privilege for members of multiple advantaged groups. Nevertheless, we suspect that that the questions we raise and the solutions we propose (see Footnote 27) may be adapted to address Alexander-Floyd's interpretation of intersectionality. For example, she endorses a black-women-centered version of the normative co-constitution thesis, referring to the "'intersecting' or co-determinative forces of racism, sexism, and classism in the lives of black women" (2012: 4). The questions we raise for the co-constitution thesis in $\$ 3$ likely also apply to this definition. 


\subsection{Methodological Tool}

There is, finally, an alternative set of approaches to intersectionality, which define it in methodological terms, as a claim about how to do social science and activism (Crenshaw 2011; May 2015: 19), rather than as a theory or hypothesis about how social reality is or ought to be. In this context, intersectionality is often referred to as a "heuristic device." It is elsewhere described as a "critique of deeply entrenched cognitive habits" (Carastathis 2014b: 305), a "knowledge project" (Collins 2015: 3), and even as a Kuhnian "research paradigm" (Hancock 2007a). Similarly, Crenshaw (2015) has recently described intersectionality as "an analytic sensibility, a way of thinking about identity and its relationship to power." Among existing interpretations, we are most attracted to (and influenced by) these, and we will say more about them in $\S 4$. First, however, we show how the various interpretations highlighted above threaten to lead to a vicious regress.

\section{Regress Problems}

Taken as a general theory, hypothesis, or law within any particular field (social metaphysics, social science, antidiscrimination policy, etc.), intersectionality faces regress problems. Intersectional theorists have noted these problems in passing but their full theoretical and practical ramifications have, in our view, not been appreciated. We begin with legal (\$3.1) and social-scientific (\$3.2) regress problems before arguing that that the regress problems generalize to any metaphysical, normative, or epistemic interpretations of intersectionality that portray it as a general hypothesis or theory $(\$ 3 \cdot 3)$.

\subsection{Regress Problems for Normative Intersectionality: Law and Policy}

Perhaps the most notorious allusion to the regress problem appears in the ruling in DeGraffenreid v. General Motors Assembly Div., Etc. (1976), discussed by Crenshaw (1989: 141-3). In this case, a group of black women alleged that GM discriminated against them by failing to hire any black women before 1964 and by firing all the black women hired after 1970, when GM downsized. Noting that GM employed women and blacks (white women and black men!), the district court issued a summary judgment that black women are not "a special class to be protected from discrimination" (Degraffenreid v. General Motors Assembly Div., Etc. 1976, cited in Crenshaw 1989: 141). The plaintiffs had to prove "race discrimination, sex discrimination, or alternatively either, but not a combination of both" (Degraffenreid v. General Motors Assembly Div., Etc. 1976). Among 
their reasons for this decision, "The prospect of the creation of new classes of protected minorities, governed only by the mathematical principles of permutation and combination, clearly raises the prospect of opening the hackneyed Pandora's box."

The court's concern seems to be that permitting claims of combined discrimination will allow all manner of gerrymandered collections of individuals to claim group-based mistreatment. While it strikes us as obvious that black women can suffer wrongful discrimination specifically as black women, other combinatory classes may not be equally obvious candidates for discrimination. The following categories are currently protected against discrimination by U.S. federal law: age (being 40 or over), disability, genetic information, national origin, pregnancy, race/color, religion, and sex. ${ }^{16}$ Are all combinations of these categories potential targets of discrimination? For example, suppose instead that GM had hired people over 40 and Muslims, but no Muslims over 40. Should federal law protect individuals not just from ageist and religious discrimination, but also from combined, age-religion discrimination? Can a group be discriminated against specifically as Muslims over 40 ? From the armchair (or the bench), initial intuitions about this example may be less clear cut, but it is not at all difficult to imagine a situation in which such a case could be made. (Imagine, say, that an ignorant and xenophobic CEO had sent a memo to HR asserting that older Muslims, unlike younger Muslims and unlike older Christians, were less likely to assimilate and "fit" into their workplace culture, and therefore should not be hired.)

But now suppose that GM had hired black women, people over 40, Muslims, pregnant people, and American citizens originally from Canada-as well as black Muslim women over 40, and Canadian-born pregnant women, etc. - but no black Muslim pregnant women over 40 from Canada. Can a group be discriminated against specifically as Canadian-born, black, Muslim, pregnant women over 40 ? It's certainly logically possible. However, if intersectionality literally means that all the various forms of group-based discrimination, in principle, cannot be understood in isolation, and must instead be understood as co-constituting, then at first glance it seems the answer must be not "possibly yes" but "necessarily yes." The answer will be yes for every possible permutation of every intersection of every social category.

The problems here are, in fact, more acute and important than they may initially appear. It is not just that the courts must allow any potential combinatory classes to pursue discrimination claims in court. Discrimination is subtle and insidious, and we may welcome general legal norms that recognize this. Yet it is also that, even if we limit the axes to the limited number recognized by fed-

16. This list is from the U.S. Equal Employment Opportunity Commission (n.d.) website. Wikipedia also lists citizenship, familial status (i.e., the category of people who have dependent children), and veteran status ("Protected Group" 2019). Both of these lists are woefully incomplete. 
eral law, class-based discrimination claims become nearly impossible to bring. Worse, if we open the door to further axes beyond those recognized by federal law, allowing indefinitely many co-constituting factors to make a significant difference to the nature of discrimination, class-based claims verge on incoherence. To see the problem, suppose a group of twelve Asian-American women allege race-based sexual harassment. If a co-constitutional intersectional model of discrimination is adopted into the legal system, it is then open to the defendants to argue, precisely because there are indefinitely many other factors, that discrimination of this kind is in-principle impossible, given the many real differences among the plaintiffs. Some, they might say, are of Vietnamese heritage, some are of Chinese heritage; some are from middle-class backgrounds, others are from working-class backgrounds; some are queer, some are straight; some speak several languages at home, some speak only English. The worry is that these twelve women cannot represent a protected class, because the discrimination suffered by the middle-class Vietnamese woman cannot in principle be the same as the discrimination facing the working-class Chinese woman. They could not claim discrimination qua Asian-American women, because each of their AsianAmerican, gendered experiences would be distinct. They could not purport to represent all Asian-American women, let alone all women of color, all women, or all people of color (cf. Crenshaw 1989: $143-149$ ). ${ }^{17}$

So, while the initial worry might be that intersectionality entails that any intersection, however gerrymandered it may seem, may constitute a protected group - and thereby strain plausibility - the second and more troubling worry is that intersectionality, taken as a general principle, entails that almost no one suffers from discrimination like anyone else. The worry is that intersectionality, taken to its "logical conclusion," entails the dissolution of social categories and therefore group-based discrimination claims altogether.

\subsection{Regress Problems in Social Science: Down the Rabbit Hole of Difference}

Analogous worries arise if we read intersectionality as a general social-scientific hypothesis, theory, or law. Recall Greenman and Xie's (2008) general claim that there is no such thing as a "pure" effect of race or gender when it comes to earnings, and their corollary insistence that the two social categories must be consid-

17. These considerations suggest a theoretical (albeit entirely impracticable and morally untenable) "solution," which is that group-based discrimination cases could at least be brought by claimants who all "checked the same boxes" for each of the protected categories, e.g., all of them the same age, all of them the same denomination of the same religion, all sharing the same bodily and cognitive (dis)abilities, etc. Even this ludicrous solution, however, only works on the assumption that the number of intersectionally relevant categories, and the subdivisions within them, is manageably small. We'll explain in $\$ 3.3$ why that assumption is false. 
ered simultaneously. Why think that the important intersections stop with race and gender? Why, for the purposes of social-scientific generalization, should considering the interactions of race and gender be sufficient? Surely attention to class, religion, geography, education status, ability, citizenship/immigration status, and age, just to name a few, will reveal that there is no "pure race-andgender" effect either.

Take sexuality, for example. Recall Pedulla's (2014) experimental finding that straight black men and gay white men suffered a wage penalty relative to straight white men, but that gay black men suffered no such penalty. Outside the lab, meta-analyses show that gay men are paid significantly less on average than straight men, whereas lesbian women are paid more than straight women (Bagri 2017; Klawitter 2015). ${ }^{18}$ These studies suggest that there is no "pure" effect of sexuality on earnings independently from race and gender. Given these intersectional complexities, what justification can social scientists give for considering only race and gender? Worse, if we take intersectionality seriously as a universal law in social science, then it seems like true generalization just as such is suspect. If intersectionality entails that social categories are indefinitely mutually co-constituting, then social reality is, at bottom, highly particularistic, which calls into question the possibility of social knowledge itself. ${ }^{19}$

One might think that the regress problem for social knowledge is a merely "academic" concern, with limited implications for research. Many social scientists, especially in informal conversation, are ready to admit that they are in the business of making knowingly "rough" generalizations, whether about singlefactor social groups (e.g., all black people) or double-factor social groups (e.g., all black women). The regress worries, they might say, can be deflected simply by including what might be called an "intersectional ceteris-paribus clause" that their generalizations will break down when more specific social groupings are examined. However, this response to the regress problem may have unacceptable political (and epistemic) effects. If intersectionality is a mere asterisk to the rough generalizations of traditional social science, then the door is once again reopened to further disappearing those who live on the margins. One of the primary impetuses for the intersectional turn is that too often abstract generalizations about the "whole group" reflect the experiences and positioning of otherwise-privileged group members, and thus render others all the more invisible, especially the smaller numerical minorities within these groups, such as LGBTQAI+ or disabled individuals.

18. Why? Much like the comparison of white women to women of color (\$1), straight married women and mothers tend to work outside the home less than their lesbian counterparts.

19. There is also a related, practical problem for social scientists of needing prohibitively large and heterogeneous sample sizes amenable to analyzing interactions between all potentially relevant intersectional variables (Cole 2009: 170; see, e.g., McCall 2005: 1786-1788). 


\subsection{Metaphysical, Normative, and Epistemic Regress Problems}

With the examples from \$3.1-2 in view, the general difficulties become apparent for the various interpretations of intersectionality and the various guises of the co-constitution thesis summarized in §2. Taken, for example, as a claim about the nature of oppression, intersectionality entails that phenomena such as "black oppression" and "white privilege" are not genuine kinds, because gender and race are "mutually constitutive" (Shields 2008: 301). According to this thesis, that is, claims about the nature of black oppression or white privilege are bound to be false or profoundly misleading unless they are articulated in relation to gender, because what it means to be oppressed in virtue of blackness differs for black men and black women. By the same token, however, "black women's oppression" isn't a genuine kind either, because gender, race, and class intersect: what it means to be oppressed in virtue of black-womanhood differs for rich and poor black women. The same goes for sexuality, ability, religion, and a host of other significant social categories, potentially ad infinitum.

The problems facing epistemic and experiential interpretations of intersectionality are analogous. We would be forced to draw the untenable and absurd conclusion that, for example, black people don't know what it's like to be black, that Latina women don't know what it's like to be Latina women, and so on. They can only know what it's like to be, say, cis queer able-bodied ... etc., members of these groups.

In fact, the range of social categories and phenomena invoked in relation to intersectionality has been remarkably extensive (and far exceeds the EEOC's grievously brief list of protected classes), to include race, ethnicity (which is, in turn, a complex construct involving numerous intersecting subcomponents, e.g., related to cultural and ancestral heritage as well as appearance, including skin color, eye color, hair, eye and nose shape, etc.), gender (which of course is not a binary phenomenon, and must be further partitioned to reflect differences related to being, e.g., cis, non-binary, trans-e.g., Bettcher 2017; Howansky, Wilton, Young, Abrams, \& Clapham 2019-or intersex-e.g., Carpenter 2014), sexuality (which is itself a complex, multidimensional spectrum), religion, geography, neighborhood, nationality, language, borders (e.g., Anzaldúa, Cantú, \& Hurtado 2012; Moraga \& Anzaldúa 2015), capitalism, colonialism (e.g., Lugones 2007; 2010), employment, education, age, generation, ability (e.g., Frederick \& Shifrer 2018), class (e.g., Brannon, Higginbotham, \& Henderson 2017), culture, height, weight (e.g., van Amsterdam 2013), relationship status, personality, facial symmetry, citizenship, migrant status, carceral status, and so on.

Surveying all these categories, one might be tempted to conclude that the co-constitution thesis ultimately entails the dissolution of groups and a return to individualism. This is the threat that Iris Marion Young (1994: 718-721) and 
Nancy Ehrenreich take the regress problem to pose. Ehrenreich's focus is particularly on the potential obstacles intersectionality creates for political activism and coalition building, pointing to "the tendency of all identity groups to split into ever-smaller subgroups, until there seems to be no hope of any coherent category other than the individual" (2002: 268). It would seem that intersectionality, which begins as an insistence on the importance of group-based categories for understanding social identity, knowledge, and justice, would devolve into another form of individualism, such that the individual becomes "the only unit of analysis, making group-based critiques of power hierarchies impossible" (2002: 271). ${ }^{20}$

But the regress does not stop at the individual. Each individual "intersects" with these categories in different ways across time and space. One cannot, for example, generalize about the political interests, privileges, or experiences of a given individual (call her Reema) without considering Reema when she is employed versus unemployed, young versus old (and her correlative changes in ability), single versus in a committed relationship, and all the changes she undergoes in neighborhood, education, health, pregnancy, parenthood, class, nationality, religion, personality, mood, and contextual specificities (e.g., what it's like for Reema when she is the only member of a marginalized group in a given context - "solo status" - versus when she is part of a "critical mass," or a slim majority, or one among many in an overwhelmingly homogeneous social setting, or when she "passes" as a member of a different group, etc.). ${ }^{21}$ Does the intersectional effort to advance our understanding of social kinds and injustices instead devolve into a social-theoretic commitment to nothing but isolated, atomic space-time points?

We take the foregoing considerations to suggest that intersectionality should

20. Ehrenreich's discussion draws on Young (1994), who does not discuss intersectionality by name, but discusses challenges against seeing women as a unified group raised by Elizabeth Spelman, Chandra Mohanty, and Judith Butler. Young (1994: 718) writes, "why does it matter whether we even consider conceptualizing women as a group? One reason to conceptualize women as a collective ... is to maintain a point of view outside of liberal individualism. The discourse of liberal individualism denies the reality of groups. According to liberal individualism, categorizing people in groups by race, gender, religion, and sexuality and acting as though these ascriptions say something significant about the person, his or her experience, capacities and possibilities, is invidious and oppressive. The only liberatory approach is to think of and treat people as individuals, variable and unique. This individualist ideology, however, in fact obscures oppression. Without conceptualizing women as a group in some sense, it is not possible to conceptualize oppression as a systematic, structured, institutional process . . . The importance of being able to talk about disadvantage and oppression in terms of groups exists just as much for those oppressed through race, class, sexuality, ethnicity, and the like as through gender." While Young and Ehrenreich refer to the regress as "infinite," they both seem to posit a stopping point, namely, at the individual, a suggestion which we complicate in the next paragraph.

21. For more on the "contextual, relational, and fluid nature of identity," see, e.g., Alcoff (2006: 146). 
not be understood as a general theoretical claim: neither an in-principle metaphysical thesis about social kinds, nor a universally applicable normative thesis about oppression, nor a general law in social science, etc. We turn next to a more promising set of interpretations.

\section{Intersectional Methodologies and Modes of Engagement}

In light of the various difficulties with defining intersectionality, including the regress problem, several authors have suggested that intersectionality is a "heuristic device" (e.g., Anthias 1998; Collins 2003: 208; Ehrenreich 2002: 276) or "analytic tool" (Collins \& Bilge 2016: 4). We believe there is room for greater clarity in what these descriptions entail as well as room to underscore the relevance of a broadly methodological approach to intersectional activism. Generally speaking, interpreting intersectionality as a heuristic (i.e., a rule of thumb) casts it as a claim about methodology, about how to do social science, or as a claim about political organizing and strategy, about how to articulate platforms and form coalitions. The idea for these theorists is that appeals to intersectionality serve an attention-redirecting function: when we are tempted to make generalizations about, or political demands on behalf of, a certain social group, invoking intersectionality often functions to remind us to, say, consider intragroup differences of a specific sort, or to consider shared forms of oppression across crosscutting dimensions of identity (Cortland et al. 2017; Movement for Black Lives n.d.; Sweetman 2018).

In this vein, Cho, Crenshaw, and McCall (2013: 787, emphasis added) claim that, "Intersectionality was introduced in the late 1980 os as a heuristic term to focus attention on the vexed dynamics of difference and the solidarities of sameness in the context of antidiscrimination and social movement politics." Similarly, Alison Bailey writes that intersectionality "is more accurately thought of as a tool (like a spell check program) used to make the plurality of women's experiences visible by alerting us to the ways some women's experiences have been excluded ..." (Bailey 2009: 20). The same way that spellcheckers in word processors can draw our attention to potential misspellings or grammatical misconstructions, we might imagine intersectionality software drawing attention to potentially problematic overgeneralizations or essentialist claims. Ann Garry builds on this analogy to suggest that intersectionality might be usefully thought of as a "method checker" or a "framework checker" (Garry 2011: 830). She writes:

by itself, intersectionality provides neither any structural analyses of oppressions and privileges nor any particular analysis of anyone's complex identity or experiences. Instead it points out what kinds of analyses 
might be useful, namely, ones that consider mutually constructed or intermeshed axes of oppression or facets of identities. . . Intersectionality helps to point us to fruitful and complex marginalized locations. It does not do the work for us, but tells us where to start and suggests kinds of questions to ask. (Garry 2011: 830, 828)

How is it, then, that intersectionality "points out" or "suggests" questions to ask? One of the most celebrated accounts of how to apply an intersectional heuristic is articulated by Mari Matsuda:

The way I try to understand the interconnection of all forms of subordination is through a method I call "ask the other question." When I see something that looks racist, I ask, "Where is the patriarchy in this?" When I see something that looks sexist, I ask, "Where is the heterosexism in this?" When I see something that looks homophobic, I ask, "Where are the class interests in this?" Working in coalition forces us to look for both the obvious and non-obvious relationships of domination, helping us to realize that no form of subordination ever stands alone. (Matsuda 1991: 1189)

Of the existing interpretations, we are most sympathetic with this heuristic, methodological approach. There are, however, outstanding questions. First, what exactly is the heuristic? Is there just one intersectional heuristic? Second, if there are multiple heuristics associated with intersectionality, what (if anything) unifies them? Third, does the heuristic view escape the regress problem? The passage from Matsuda seems to suggest that the process of asking the other question might never end. Are there infinitely many other questions to ask? If so, is this yet another problematic form of intersectional regress?

\section{Intersectionality and the Regulative Principles of Reason}

"Hegel seems to me to be always wanting to say that things that look different are really the same. Whereas my interest is in showing that things which look the same are really different. I was thinking of using as a motto for my book a quotation from King Lear: 'Ill show you differences.' [laughing:] The remark, 'You'd be surprised' wouldn't be a bad motto either."

-Ludwig Wittgenstein (1948, reported in Drury 1996: 157)

We believe that progress on these questions can be made if intersectionality is taken to have what Immanuel Kant calls a "regulative" rather than a "constitu- 
tive" or descriptive function. That is, we propose that intersectionality can be understood as a regulative principle or ideal rather than as a general empirical or metaphysical theory purporting to directly describe social reality, or as a general normative theory purporting to describe the nature of oppression. In this section, we offer some brief background to the Kantian notion of a regulative principle (\$5.1). Then we show how intersectionality can be plausibly modeled as regulative in this sense ( $\$ 5.2-3)$, and thereby shed light on the commonalities between alternative conceptions of intersectionality. We then sketch, in broad terms, some of the theoretical and practical benefits to unifying existing interpretations of intersectionality and articulate some of the risks of abandoning efforts toward a unified interpretation $(\$ 5.4)$, and we illustrate, in specific terms, how the intersectional regulative ideal applies in practice, in both theoretical, social scientific (\$5.5) as well as social-political movement contexts (\$5.6). Finally, we show how modeling intersectionality as a regulative ideal avoids the vicious regress $(\$ 5.7)$.

We should note at the outset that, while our interpretation of intersectionality draws on ideas developed by Kant, what follows is not intended to be a close scholarly reconstruction of his considered views. ${ }^{22}$ Our goal is to use the Kantian notion as a rough model, or to use Kant, as much as he might have protested, as a mere means to our own ends. ${ }^{23}$

\subsection{Regulative Ideas}

It is internal to the nature of reason, according to Kant, that, as inquirers into nature, we aim at an ideal of systematicity (Kant 1999: A645/B673). ${ }^{24}$ In the ad-

22. Interpretive questions regarding Kant's views of the regulative ideas of reason abound. For example, does Kant radically revise his view of the ideal of systematicity between the first and third Critiques? If so, how and why? Does the ideal of systematicity apply to the organization of empirical concepts, or also in the very formation of empirical concepts? Is the presumption of systematicity in nature a mere heuristic, for Kant, or does it have any objective import? Are Kant's claims about the necessary regulative use of the transcendent, non-empirical, nearly empty ideas of "God," the "soul," and the "world-whole" at all defensible? There are further broader (deeper) interpretive questions about how the regulative ideas of theoretical reason relate to practical reason and the unity of reason more generally. We do not treat these here.

23. There are several reasons why Kant is such an extremely unlikely resource for thinking about intersectionality. Most significantly, Kant endorsed explicitly racist positions, including a theory of race that claimed that certain races are permanently inferior (see, e.g., Allais 2016; Kleingeld 2007; Mills 2017), as well as explicitly sexist positions, including that women are "immature in civil matters" (Kant 2006 Ak7:209) and merely "passive" citizens who cannot vote (1996 Ak6:315). (We use the standard Academy pagination for all references to Kant.) For more on Kant's sexism, see the papers collected in Schott (2007), especially Rumsey (2007). See also Marwah (2013).

24. For a more recent spin on similar themes, see, e.g., Kitcher (1999) and for a survey of contemporary and historical questions about the unity of knowledge and science, see Cat (2017). For an introduction to Kant's views about reason, see Williams (2018). 
vancement of knowledge, we should have an eye toward whether our newly formed concepts and beliefs systematically cohere with our prior concepts and beliefs. Operating with the aim of systematicity directs us how and where to look for new information. But this ideal, for Kant, is merely regulative. That is, it is an aim that we must assume to advance inquiry, but does not thereby also theoretically posit anything about what nature is actually like, or about what we, necessarily, will be able to achieve through inquiry. ${ }^{25}$ In fact, Kant denies that we are or ever will be in a position to assert that nature, as we know it empirically, is in fact globally systematic. That is, he denies that we can know whether the elements of nature actually cohere as a unified system describable by a unified overarching empirical law. The ideal of systematicity instead has a purely regulative use.

To elaborate the content of the ideal of systematicity, Kant introduces three criteria, which he refers to as the principles of homogeneity, specification, and affinity. An empirical inquiry aims at systematicity only if it:

a) homogeneity: aims to unify diverse concepts or findings under higher, or more general, concepts or laws

b) specification: aims to specify difference or deviation within existing empirical categories or classifications

c) affinity: pursues a continuity of forms, according to which:

i. for any two given distinguished species, or groupings, $a$ and $b$ there is some higher genus, or grouping, $g$ (if we ascend high enough) that reflects some property $p$ shared by $a$ and $b$, and

ii. for any given species or grouping $s$ there are distinct subspecies $x$ and $y$ that have different properties $c$ and $d$ while sharing the property $e$ essential for membership in s. (See Guyer 1990: 24)

Let's consider some (simplistic) examples. We pursue the principle of homogeneity when, for example, we seek higher genera given a certain diversity of species. Suppose we've distinguished two groupings of animals, feline and canine. Homogeneity as a principle of reason tells us, in seeking new knowledge, to search for some way of unifying the two. So, we investigate the properties they share and ultimately posit the higher genus, mammal. Similarly, suppose I am committed to the existence of two given fundamental forces, such as electricity and magnetism. The aim for rational systematicity, via the principle of homogeneity, directs me to seek a higher more general fundamental force (in this case, electromagnetism) that explains and unifies the lower forces.

25. Arguably, for Kant, we must assume that it is at least really possible that we will be able to achieve systematicity in our empirical laws in this sense. 
Now consider the principle of specification. Suppose I've posited the animal grouping, canine. Specification compels me to seek important differences within this grouping such that I discover a diversity of subspecies, for example, domestic dogs, coyotes, and wolves. Similarly, due to the way specification guides inquiry, we might seek out variety in the ways a given general empirical principle or law is instantiated in different contexts. I may be, for example, compelled to inquire into whether there are important differences in the way, say, gravitational forces apply to large celestial bodies as opposed to teeny tiny bodies.

Notice that in these examples, the regulative principles operate to guide inquiry in light of some antecedent concepts, classifications, or principles, but with the aim of uncovering new higher general concepts or principles or new lower further-specified categories. They are "maxims" for gathering new knowledge in light of existing classifications and so are, at least in part, of a higher-order nature. In neither case is it posited, from the outset, that we necessarily will discover this or that unity or diversity in any given case. Rather, while we bring our assumptions and principles of reason to nature, what we empirically find may or may not itself be systematic.

Kant's discussion of the regulative principles focuses on natural science, but we can see how the principles of unity and specification apply in more obviously social domains. We find the principle of homogeneity at work in, say, inquiring into the similarities in the ways that both pregnant and disabled people are excluded from the workplace via architectural design and social stigma. We find the principle of specification at work when we inquire into the disparate impact of facially race-neutral voting requirements on members of different racial groups. As guiding principles of reason, we should expect to find instances of them in all areas of inquiry.

\subsection{Intersectionality as a Regulative Ideal}

At this point, readers may have already noticed similarities between intersectionality's imperative to "ask the other question," and Kant's principle of specification. One aspect of the intersectional critique is that feminists, race theorists, and social scientists historically pursued homogeneity (i.e., unification and simplification) too single-mindedly, to the exclusion of specification. Generalizations about the nature of these social categories, and how they relate to power and inequality, tend to ignore the specific experiences and forms of discrimination faced by members of multiple disadvantaged groups. There is some precedent for understanding intersectionality in this way. For example, Warner, Settles, and Shields (2016: 173) write that:

intersectionality disrupts traditional paradigms in psychology ... by 
challenging a long-standing value within psychology that the best theory and explanations for phenomena are those that are the most parsimonious. An emphasis on parsimony suggests that simplification is an important aspect of a strong psychological analysis. Intersectionality suggests that a theory or explanation may not apply to all groups; rather, relationships and outcomes may vary depending on intersecting identities ... intersectionality may challenge the psychologist's ability to derive a single, universal, parsimonious theory or explanation.

Intersectional approaches to social reality and oppression very often reveal significant diversity where there had been an assumed homogeneity. In many cases the assumed homogeneity is the result of a problematic generalization, for example, when white middle-class women treat their experiences and interests as representative of all women. This problematic universalizing can occur along many axes of privilege, including whiteness, maleness, able-bodiedness, cisness, and wealth. Intersectionality directs us to challenge this (false or misleading) homogeneity; similarly, according to Kant's regulative principles, coming to a more systematic view of things requires that we must always seek diversity within apparently homogeneous categories.

But the principle of specification is not equivalent to intersectionality. For Kant, systematicity is the ideal or aim of knowledge as such, understood as a neutral, unbiased, and largely individual enterprise. The histories of critical feminist philosophy and sociology of science have taught us that science, in fact, does not operate in this ideal way (Crasnow, Wylie, Bauchspies, \& Potter 2018). Kant simply did not imagine the ways that political and social-cognitive factors influence which unities and specificities actually get pursued. Intersectionality, by contrast, emerges from and is situated within traditions of social thought that emphasize that the generalizations we make, and who gets to make them, are inevitably political. Kant's regulative principles do not account for this.

Given the realities of bias and privilege, an inquirer into social reality might sincerely and wholeheartedly pursue Kant's regulative principles of unity and specification without adopting a genuinely intersectional methodology, and perhaps without ever arriving at an intersectional question or claim. Consider the study of sexuality. Suppose a naïve theorist originally believed different-sex attraction was the only kind of sexuality, but eventually (following the principle of specification) hypothesized that there were two types: different-sex and samesex attraction. Enter the Kinsey scale of sexuality, which challenges this traditional sexuality binary. On the original 7-point Kinsey scale from 1948, all males are said to fall within two poles of sexuality, "exclusively heterosexual" and "exclusively homosexual," with relatively few males falling at the poles themselves (Kinsey 1998). Arguably the Kinsey scale follows the principle of specifi- 
cation, revealing new diversity within an existing simplistic binary classification scheme. Yet the Kinsey scale itself fails not only with respect to gender diversity (initially focusing only on cis men and the traditional gender binary), ${ }^{26}$ it also fails to investigate the interaction of other classifications with its central categories of sexuality. So, although it specifies, it is clearly not intersectional.

Similarly, we can imagine a researcher who devotes their career to studying race and along the way discovers, as a result of following the principle of specification, that whiteness has been constructed, interpreted, and demarcated in different ways across time and space. Suppose the researcher comes to see that the present-day experiences and privileges of "American whiteness" differ in important respects from those of, for example, "Australian whiteness" and "European whiteness." Then the researcher might realize that European whiteness itself must be further specified into Scandinavian, German, Eastern European "whitenesses," and so on. Conversely, the researcher might come to identify previously unappreciated similarities between different manifestations of whiteness, for example, exploring the shared legacy of segregation on the present-day experiences and privileges of South-African and Southeastern-American whiteness, and so on. The researcher could indefinitely seek out such similarities and differences among the multifarious constructions of whiteness, and thereby advance our understanding of whiteness in numerous respects, without ever investigating the intersection of whiteness with gender, sexuality, class, or ability. They might, despite conscientiously following the principles of specification and homogeneity with the best of epistemic intentions and to the best of their investigative abilities, never stop to consider whether, say, whiteness confers different privileges on men versus women, on the wealthy versus the workingclass, and so on. In this example, the sincere social inquirer searches for unity and diversity within a single classification scheme (namely, a geographicallydistributed ethnic-racial classification scheme) without considering forms of unity and diversity that might emerge across separate classification schemes (i.e., what emerges when racial and gender classification schemes are considered in tandem).

Pursuing intersectionality is thus not reducible to pursuing any of Kant's principles, or their combination. This should not be surprising. It is possible to earnestly pursue specification and homogeneity (i.e., diversity and unity) without adopting an intersectional approach or raising an intersectional question. Seeking out specification and homogeneity is, we believe necessary, but certainly not sufficient, for an intersectional approach.

We believe that intersectionality fills some of the gaps in and corrects some

26. For efforts to formulate richer and less exclusionary measures of sexuality, see Galupo, Lomash, and Mitchell (2017). Note also that Kinsey's research did explore race- and class-based differences in sexuality. These differences are not reflected in his one-dimensional scale. 
of the mistakes of traditional social inquiry because it is premised on the lived realities of injustice. It is a concept first born out of the experiences of practical, epistemic, and hermeneutical injustice faced by women of color at the hands of white feminisms and traditional race theories. In seeking unity and diversity, intersectionality looks for the ways existing concepts or categories interact, but it looks with a particular purpose, namely that of correcting injustice (e.g., erasure, marginalization) within those existing categories. Intersectionality therefore should be considered an independent regulative ideal on all forms of human and social inquiry. It is a regulative ideal for non-ideal scientific and activist communities in a non-ideal world.

\subsection{The Content of the Ideal}

As we understand it, the intersectional regulative ideal has two components or aspects. One component of the ideal calls for treating existing classification schemes as if they are indefinitely mutually informing. The directive is to seek out new or underappreciated ways in which different, ostensibly comprehensive but single-factor schemes for classifying individuals (by race, gender, class, etc.) can be analyzed in tandem. Following this directive will reveal new or underappreciated unity and diversity within and across existing theoretical and practical schemas. Like the Kantian regulative principles, the ideal does not imply a priori that these distinctive schemes are necessarily or will inevitably turn out to be mutually informing, but rather that it is an imperative that we must seek out the ways they might be, in gathering new knowledge about human beings and social reality. Whether an inquiry reveals an actual interaction in a given case, and when an intersectional analysis will be fruitful, are, on this model, both empirical questions. It is possible that we may not find the "intersectional result" that any two or more schemes are in fact mutually informing.

However, to interpret the intersectional ideal as nothing but the mandate to treat classification schemes as if they are mutually informing would be to strip it of its intrinsic critical meaning. Intersectionality emerged from critical discourses the central aims of which were to understand and resist injustices, including marginalizing tendencies in social theory and practice (Bilge 2013; Dhamoon 2011). Thus a second component of the intersectional ideal is explicitly and essentially political. In understanding human beings and their positions in the world, intersectionality aims to train our theoretical and practical gazes on the ways that injustices influence the production of knowledge and meanings, the formation of identities and experiences, and the constructions of social institutions, practices, and policies. The ideal must make essential reference to questions related to power, privilege, inequality, and injustice. In respecting both of these aspects of intersectionality, we suggest the following formulation of the ideal: 
GENERAL MAXIM OF INTERSECTIONALity: (a) Treat social classification schemes, groupings, or categories as if they are indefinitely mutually informing, (b) with the aim of revealing and resisting inequality and injustice. ${ }^{27}$

The content of the ideal thus involves two essential aspects, the first (a), much like the Kantian regulative principles, tells which general kinds of things to look for (interactions between existing classifications or groups), while the second (b), very much unlike the Kantian principles, tells how and why to look for them (with the aim of resisting injustice and inequality, which may be involved in the very construction of those classification schemes or categories).

This general maxim of intersectionality can then be applied to particular domains to generate more specific heuristics. For example, applying the ideal to the epistemological domain, we might generate the following more specific maxim:

EPISTEMIC MAXIM OF INTERSECTIONALITY: Treat existing classification schemes (or categories) as if they are indefinitely mutually informing with the aim of revealing and resisting the effects of inequality and injustice on the production, transmission, access, and retention of knowledge.

Similarly, applying the ideal to the production of meanings and interpretations, we can generate the following heuristic:

HERMENEUTICAL MAXIM OF INTERSECTIONALITY: Treat existing classification schemes (or categories) as if they are indefinitely mutually informing with the aim of revealing and resisting the effects of inequality and injustice on the production, transmission, access, and retention of meanings, images, and narratives.

Likewise, we can apply it to the formation of political coalitions:

COALITIONAL MAXIM OF INTERSECTIONALITY: Treat existing classification schemes (or categories) as if they are indefinitely mutually informing with the aim of revealing and resisting the effects of inequality and injustice on the formation, interests, platforms, strategies, and sustaining of political coalitions.

27. While our interpretation departs from those of Alexander-Floyd and others (\$2.5), according to which intersectionality should focus primarily on black women, this ideal could be adapted to say, for example, "(a) Treat social classification schemes as if they are indefinitely mutually informing, (b) with the aim of revealing and resisting inequality and injustice in the lives of black women." 
We can generate similar intersectional heuristics for theorizing about the creation of identities or subjectivities; for the construction of social institutions and policies; and for the analysis of psychological categories and kinds (including desires, stereotypes, and biases). For this reason, modeling intersectionality as a regulative ideal represents one way to bring some unity to the various and multifaceted interpretations and applications of intersectionality. We can see how pursuing the ideal (i.e., following these maxims) can help us to uncover the ways certain social categories or identities can be mutually informing (e.g., blackness, womanhood); how certain forms of oppression interact (e.g., homophobia, sexism); how certain experiences are constructed (e.g., the painful "in-betweenness" of the experiences of the historically colonized; Anzaldúa et al. 2012); and how certain identities end up being marginalized in political discourse. It also explains how intersectionality is as much about uncovering intergroup similarities and shared struggles as it is about revealing differences ( $\$ 5.6$; see also Collins 2003: 207; Cole \& Luna 2010; Doetsch-Kidder 2013; Moraga 2015: 29). It guides us to search for common forms of oppression for members of groups that are disadvantaged along different axes, for example, sexual and racial minorities (Cohen 1997; Cortland et al. 2017). By applying intersectionality as a general regulative ideal to particular domains we also arrive at some unity with respect to the different heuristics currently associated with intersectionality, including Matsuda's (1991) normative heuristic, "Is there $x$-ism in this y-ism?" 28

Interpreting intersectionality as a regulative ideal models it as a methodological principle, but diverges from some existing methodological approaches in significant ways. For example, Ange-Marie Hancock (2007a; 2007b) argues that intersectionality is a Kuhnian research paradigm. There is much to recommend Hancock's methodology-centered analysis, which is one of those most closely aligned with, and influential upon, ours. (Consider, e.g., Hancock's, 2016: 16, recent description of intersectionality as "a pathbreaking analytical framework for understanding questions of inequality and injustice.") However, Hancock has elsewhere identified some limitations with interpreting intersectionality as a research paradigm (Hancock 2013), and we suspect there are others. ${ }^{29}$

Specifically, classifying intersectionality this way risks being both too narrow (by not covering enough cases) and too broad (by incorporating commitments that, we think, intersectional theorists should resist). It may be too narrow

28. For an extensive list of potential heuristics to guide investigation across numerous stages, see Cole (2009: 172).

29. In still more recent work, Hancock adopts a "hybrid" account of intersectionality that, on the one hand, treats it as a methodology, and, on the other hand, treats it as a commitment to demarginalizing women of color (cf. §2.5). Hancock (2016: 33, original emphasis) writes, "Intersectionality's intellectual project is thus twofold: an analytical approach to understanding betweencategory relationships and a project to render visible and remediable previously invisible, unaddressed material effects of the sociopolitical location of Black women or women of color." 
insofar as scientific paradigms are usually disciplinary and domain-specific, and inherently committed to a narrow set of methods, whereas intersectionality is a methodological imperative reaching across existing research paradigms, disciplinary boundaries, and methods of knowledge production and activism. Intersectionality is as much an ideal for studying unjust social institutions and the nature of oppression as it is for research in psychology or medicine. It is a guiding aim of both quantitative and qualitative research, as well as various hermeneutical and artistic projects, including memoir, poetry, and countless others. Conversely, modeling intersectionality as a Kuhnian paradigm may also be too broad and theoretically committal, insofar as scientific paradigms fundamentally involve commitments to general theories, laws, and principles, some of which are taken to directly describe reality in general ways. Operating within a research paradigm means engaging in what Kuhn calls "normal science," which depends on a consensus about the basic laws governing the objects of study, and precisely how best to study them (taken-for-granted "rules that tell the practitioner ... what both the world and his science are like") (Kuhn 1996: 42). ${ }^{30}$ In effect, we worry that treating intersectionality as a paradigm threatens to smuggle in the co-constitution thesis as a general law internal to the paradigm, which would lead to the regress problem $(\$ 3, \S 5 \cdot 7)$.

\subsection{Why Unify?}

Our interpretation represents one way among many to see how different invocations of intersectionality hang together (see, e.g., §2.3 for others). However, it is reasonable to step back and ask why a unified interpretation is desirable in the first place. ${ }^{31}$ After all, as we mentioned in $\$ 5.2$, some argue that one of intersectionality's principal teachings is to resist efforts to articulate overly parsimonious empirical theories or to form artificially unified coalitions, insofar as these efforts threaten to obscure intragroup differences (Warner, Settles, \& Shields 2016: 173). Intersectional scholars have rightly highlighted the perils of certain projects of unification, or "universalizing tendencies" (Alexander-Floyd 2012). Crenshaw

30. See, e.g., Nickles (2017: Section 3.1): "As its name suggests, normal science is the default state of a mature science and of the community of researchers who constitute it. The paradigm informs investigators what their domain of the world is like and practically guarantees that all legitimate problems can be solved in its terms. Normal science is convergent rather than divergent: it actively discourages revolutionary initiatives and essentially novel (unexpected) discoveries, for these threaten the paradigm." Operating within a research paradigm is often antithetical to the open-ended exploration and persistent commitment to demarginalization which we take to be partly constitutive of intersectionality. Kuhn writes, "No part of the aim of normal science is to call forth new sorts of phenomena; indeed those that will not fit the box are often not seen at all" (1996: 24).

31. Thanks to an Ergo referee for urging us to address this question. 
(1991: 1244), for example, stresses that she is not offering "some new, totalizing theory of identity." Perhaps pursuing a unified account of intersectionality, just as such, faces similar pitfalls.

While we agree that the perils of unchecked unificationism are real (indeed, these pitfalls are central to our analysis), there are perils of unchecked anti-unificationism as well, as existing scholarship by women of color teaches. Consider Uma Narayan's (1997: Chapter 3) analysis of the racist tendency in the United States to interpret dowry murder as an "exotic" cultural practice endemic to Hinduism or South Asia, when it is in reality highly similar and continuous in profound ways with patterns of domestic violence in America and elsewhere. This "othering" of "Hindu culture" is itself oppressive and leads to false exoticizing ideas.

Similarly, there are risks in not pursuing any unity in the way we think about intersectionality, especially given existing power relations in the construction of knowledge. For one, the term may become so variously used that it is, or is viewed by some as, "thinned out," and thus consequently abused, dismissed, or relegated to vacuous "buzzword" status (\$2.4-5). For another, there are risks of epistemic loss and missed opportunities for coalitions when we fail to see an intersectional phenomenon as intersectional. Collins (2015: 15) writes about the puzzled reactions she received after giving a talk on intersectionality at the Afro-Latin and Afro-Caribbean Women's Festival in Brazil, when she was approached by a group of Afro-Brazilian women scholar-activists who thought that intersectionality "had nothing to do with" them. According to Collins, they were engaged in an intersectional social justice project without knowing it and under the impression that intersectionality was just for white feminists. At a minimum, cases like this illustrate the live possibility of talking past each other in scholarly and activist intersectional endeavors (a practical cost) and of losing knowledge (a theoretical cost). The implications of such misunderstandings should not be underestimated. Not being able to see one's movement or project as intersectional could mean missing out on the existing wealth of intersectional resources and history to draw on. Recognizing what's shared across diverse intersectional endeavors is thus also a matter of hermeneutical justice, of having conceptual resources adequate to the tasks of understanding and articulating social experiences of oppression. Such misunderstandings can, moreover, clearly put up obstacles to coalition-building. Two grass-roots intersectional movements are presumably less likely to seek opportunities to work together to the extent that one proudly adopts the label "intersectional" while the other interprets that label as meaning "for white feminists only."

We therefore conclude that unified interpretations of intersectionality (especially those that remain cognizant of the perils of unificationism) can offer both theoretical and practical value. Specifically, interpreting intersectionality 
as a regulative ideal makes it clear that intersectionality is not a label or badge that a movement or lab can earn once and wear forever; it is an ever-present imperative, guiding research and activism over time. For example, it is not enough to invoke intersectionality in the initial articulation of a movement platform or social theory; the regulative ideal applies continuously and critically as movements and research programs develop. It directs all practitioners to stay vigilant about the risks of further marginalizing less visible members of groups, as well as to stay on the lookout for intergroup similarities and shared aims. In the final three sections, we illustrate how the intersectional regulative ideal applies in social science ( $\$ 5.5)$ and activism ( $\$ 5.6)$, and makes generative, forward-looking contributions to inquiry and activism $(\$ 5 \cdot 7)$.

\subsection{Applying the Ideal in Social-Scientific Practice}

For a better sense of what intersectional methodology entails, it may help to see how the regulative ideal applies in practice. Recall Pedulla's (2014) study on salary discrimination. For the purposes of illustration, we might imagine that the research proceeded along the following lines. Pedulla could have started with the observation that race affects income. This is apparent in the overall average data. The intersectional ideal then directs him to treat social classification schemes as if they are mutually informing, in a way that reveals and resists the effects of inequality and injustice. The ideal thus instructs him to consider the way that current understandings of inequality might interact. In this case, Pedulla considers whether race and sexuality are mutually informing when it comes to income, and looks for unjustly marginalized group members whose experiences and positioning are wrongfully obscured by the overall average. So he asks, "Is there heterosexism in this racism?" At this stage he is pursuing diversity (specification), hunting out subtypes and exceptions to existing generalizations. He might have hypothesized an additive disadvantage here (sometimes referred to as "double jeopardy"), such that gay black men suffer an increased penalty relative to straight black men. However, he finds the surprising result that gay black men do not (in this specific context) suffer an additive disadvantage and, unlike straight black men and gay white men, are not offered a lower salary than straight white men (see also Wilson et al. 2017).

Now that he has uncovered this diversity, he is led to ask why. He transitions to a new stage of inquiry (unity, or homogeneity), seeking out more general social hypotheses that might explain the deviation from the more simplistic generalization. In this case, Pedulla had (in fact, not just in our fictionalized illustration) hypothesized that psychological stereotypes intersect. He measured participants' perceptions of how threatening and feminine the job applicants were. Black men are stereotyped as threatening and hyper-masculine (e.g., Johnson, 
Freeman, \& Pauker 2012), whereas gay men are stereotyped as feminine (e.g., Petsko \& Bodenhausen 2019). In the case of the gay black male applicant, these two stereotypes "canceled out": he was perceived as less threatening because of his perceived femininity, and these perceptions in turn predicted his salary. In this case, a broader, unifying explanation refers to the cognitive operations of participants' stereotypes. In this way Pedulla's exploration of stereotypes about femininity injects a further intersectional dimension into the inquiry, by unearthing sexism within existing racist homophobia. The three classification schemes of racism, sexism, and homophobia are mutually informing in the psychological context of stereotype activation and application.

To reiterate, we do not mean to suggest that intersectionality is only theoretically at home in quantitative social-scientific investigations like Pedulla's. The ideal applies across a broad range of epistemic projects. Thus we part ways with Nash who regrets that we have "not yet developed a rigorous method of examining multiple subject positions" (2008: 4-5). On our view, this is a feature, not a bug. Social scientists, metaphysicians, and other theorists can hunt for mutually informing categorization schemes, in-group differences, and betweengroup similarities in myriad ways. There is no need to "prioritize" multifactor quantitative analysis over, say, qualitative interviews and case studies of specific groups. Modeling intersectionality as a regulative ideal is thus consistent with Bright, Malinsky, and Thompson's (2016: 62) call for a pluralistic understanding of intersectional methodologies.

\subsection{Applying the Intersectional Ideal in Activism}

It is also important to see how intersectionality as a regulative ideal is a maxim for activism and coalition-building. Consider Veronica Terriquez's (2015) rich analysis of the complex intersections between immigrant and LGBTQ activism. In the early 2010s, undocumented immigrant youth (DREAMers) sought to both destigmatize their status and catalyze the movement toward immigration justice. For the purposes of illustration, we might imagine that the intersectional ideal directed them to ask how different identity-based movements might mutually inform their respective struggles to resist injustice. In this case, the activists effectively asked, "how can queer activism inform the immigration rights movement?" They began by seeking common ground across social difference (unity, homogeneity), finding inspiration from the queer "coming out of the closet" narrative. DREAMer activists then organized a "Coming Out of the Shadows" initiative, whereby they "publicly declared their undocumented status in order to combat the stigma associated with their precarious legal situation and humanize their experiences in the eyes of broader audiences" (Terriquez 2015: 344).

Concurrently, the DREAMer movement also turned inward (specification), 
toward the multiply marginalized individuals within their community, asking (in effect), "Is there heterosexism within immigration activism? Is our movement too focused on undocumented youth who are 'otherwise privileged' in virtue of being straight and cis?" In fact, queer undocumented youth face distinctive forms of heterosexism. As Terriquez (2015: 352) and one of her interviewees explain:

Most DREAMers, regardless of their sexual orientation, relied heavily on family and extended networks for their economic survival and other resources. Loss of family financial support was a real concern for some LGBTQ activists, as 24-year-old Samir asserted: “We can't [legally] have jobs, so we already have these financial issues. Once you come out to your family-and if they don't respond very well-then there is that chance of losing your bed, a place to sleep. There's a lot more you can lose because you can't really take care of yourself financially when you're undocumented."

To both draw attention to and empower undocumented queer youth, immigration groups invested in several strategies. They created the Queer Undocumented Immigrant Project, which aimed to promote LGBTQ leadership in immigration groups, and Queer Dream Summer, which set up internships for undocumented queer youth in LGBTQ organizations (Terriquez 2015: 355). Immigration rights groups also organized workshops, on campuses and in wider communities, to introduce "straight members to the experiences of the movement's queer-identified members," including "testimonials from queer members about their LGBTQ coming out experiences and the impact of homophobia on their lives" (2015:355). Notably, this attention to intragroup difference (specification) did not function primarily to subdivide immigration groups (much less did it form an endless regress toward individualism), but had just the opposite (unifying) effect, drawing "connection setween living in the shadows and living in the closet" (2015: 355). Lifting up the voices of multiply marginalized group members did not tear the movement apart. It ultimately highlighted points of common humanity and struggle across crosscutting dimensions of social difference.

These strategies paid numerous dividends. Adopting the coming-out narrative not only inspired undocumented youth to leave "the shadows," but also inspired queer undocumented youth to come out as queer. As the coming-out narrative "traveled" out of its original LGBTQ context, it also traveled "back around" and reciprocally reinforced queer activism. Terriquez refers to this as a "boomerang effect," whereby "strategies originated by movement A are borrowed by movement B in pursuit of separate goals; yet in employing that strat- 
egy, movement B ends up furthering the aims of movement $A^{\prime \prime}$ (2015: 347).

The courage and strength that undocumented queer youth found in coming out not once but twice helped these doubly-marginalized individuals become doubly empowered, or, as Terriquez says, "intersectionally mobilized." Specifically, she offers tentative grounds to think that undocumented queer youth are even "more civically engaged than their straight-identified peers" (2015: 344), and especially well-represented in leadership positions in immigrant rights groups. "LGBTQ individuals, who first become empowered around their sexual orientation as a result of their ties to the LGBTQ movement, were primed to come out with respect to their other identities and play a leadership role in another movement" (2015: 347). Thus, recognizing multiply disadvantaged subgroups need not lead to internal division within a movement, but rather may very well increase activism within that subgroup, the members of which may then take on leadership roles in the organization (see also King 1988: 54). Terriquez concludes "that attention to the interests, needs, and unique experiences of and by groups who experience multiple identity-based hardships . . . can not only assist these groups in overcoming barriers to political activism, but also inspire high levels of commitment and activism" (2015: 358).

This insight is firmly in keeping with the black-feminist tradition, and resonant with, for example, Audre Lorde's celebrated argument for the productive rather than destructive power of difference:

Difference must not be merely tolerated, but seen as a fund of necessary polarities between which our creativity can spark like a dialectic . . . Difference is that raw and powerful connection from which our personal power is forged. As women, we have been taught either to ignore our differences, or to view them as causes for separation and suspicion rather than as forces for change ... But community must not mean a shedding of our differences, nor the pathetic pretense that these differences do not exist. (2012: 111-112)

She called instead for "learning how to take our differences and make them strengths."

Of course, Terriquez also emphasizes that reciprocally reinforcing boomerang effects are by no means guaranteed to occur when one movement "borrows" another's strategies. First, such strategies risk appropriation as much as collaboration (see also §2.5). Second, and relatedly, boomerang effects don't just happen; they depend on cooperative agency, and likely "require intentional efforts by activists to bridge two movements" (2015: 348). But lastly, the "intersectional result" in this case, of generating mutually reinforcing activist momentum across distinctive movements, may simply never materialize. Again, qua regulative ideal, 
the intersectional activist ideal directs us to look for such reciprocal movementenriching opportunities. The benefits of boomerang effects are obvious - making intersectional social movements stronger than the sum of their parts-but there is no guarantee that they will appear.

\subsection{Escape the Regress Problem?}

We are now in a position to see how modeling intersectionality as a regulative ideal avoids the regress problem. A vicious regress arises only if we commit to a version of the co-constitution thesis according to which some aspect of social reality (or experience, identity, oppression, etc.) is in all cases and indefinitely intersectional. The vicious form of the regress arises only if we adopt the coconstitution thesis as a general law - that is, as universally true of a given domain. Treating the co-constitution thesis this way calls into question the validity of social categories, kinds, or generalizations as such. If all social categories are mutually co-constituting and there are indefinitely many social categories, then the regress takes off a priori, and thereby demands that we find a stopping point, or solution, for the regress from the armchair. Worse, insofar as the coconstitution thesis is precisely intended to be a thesis about the nature of social groups (kinds or generalizations), and because the regress entails that there are no such groups, the co-constitution thesis is unavoidably self-undermining.

Yet if intersectionality is a regulative ideal, then we do not commit to the coconstitution thesis, and there is no vicious regress. Pursuing the ideal will sometimes be fruitful and sometimes not, and, in any given case, we may not arrive at "intersectional results." It's always an empirical question (not one that follows from a general law a priori) where intersectional inquiry (on a given topic) will stop (see also Garry 2011; Hancock 2007a; 2007b; Haslanger 2014; May 2015; McCall 2005).

In another sense, however, the methodological view does entail a regressbut it is productive rather than vicious. In pursuing the intersectional ideal, we will continue to seek out further discoveries, to continually ask new "other questions." But this is a good thing. We want our scientific methodologies as well as our modes of activist engagement to be generative, such that each answer generates a new set of questions.

Intersectionality compels us to seek out further practical and theoretical discoveries: unity across groups (intergroup similarities) as well as variety internal to groups (intragroup differences), to find out whose experiences are obscured by prevailing theoretical and activist schemes of representation, to seek out new grounds for solidarity and boomerang effects across crosscutting dimension of identity, and so on. But it does not imply that every particular category will be indefinitely diverse, or that, in literally every case, no meaningful and true gen- 
eralizations can be made about a racial group, or a gendered racial group, without cross-referencing the claim with other classification schemes. Investigations into further intersections may not be useful or fruitful, and so may not change the results obtained from higher-level generalizations. In these cases, the social world may stop the regress on its own (see also Yuval-Davis 2006: 202-203).

To the extent that there is a methodological regress, then, we should embrace it. Just as Kant wrote that "cognition requires an advance to the always still remaining differences" (A656/B684), so, too, have intersectional scholars argued that the intersectional regress is productive. Kathy Davis (2008: 77) writes, "The infinite regress built into the concept [of intersectionality] - which categories to use and when to stop - makes it vague, yet also allows endless constellations of intersecting lines of difference to be explored." Modeling it as a regulative ideal shows, we hope, that intersectionality is not so vague after all.

\section{Acknowledgments}

The authors contributed equally to writing this essay. We are grateful for constructive feedback from Greg Anthill, Cory Aragon, Cameron Evans, Tempest Henning, Brian Kim, L. Lin Ong, Peter Ross, Jennifer Saul, Joseph Shin, Peter Thielke, anonymous referees at Ergo, and especially Julie Tannenbaum, as well as numerous others at the Philosophy of Social Science Roundtable, University of South Florida in Tampa in March, 2016; the conference Who's Got the Power? Philosophical Critique of Social and Political Structures, University of Iceland in Reykjavik, October 2017; the World Philosophy Day celebration at Cal Poly Pomona in November, 2017; the Philosophy Department Colloquium Series at Pomona College in November, 2018; and the Central Division of the American Philosophical Association in Denver, February, 2019.

\section{References}

Alcoff, Linda Martín (1991). The Problem of Speaking for Others. Cultural Critique, 20, 5-32. https://doi.org/10.2307/1354221

Alcoff, Linda Martín (2006). Visible Identities: Race, Gender, and the Self. Oxford University Press. https://doi.org/10.1093/0195137345.001.0001

Alexander-Floyd, Nikol G. (2012). Disappearing Acts: Reclaiming Intersectionality in the Social Sciences in a Post-Black Feminist Era. Feminist Formations, 24(1), 1-25. https:// doi.org/10.1353/ff.2012.0003

Allais, Lucy (2016). Kant's Racism. Philosophical Papers, 45(1-2), 1-36. https://doi.org/10.1 080/05568641.2016.1199170

Anthias, Floya (1998). Rethinking Social Divisions: Some Notes towards a Theoretical 
Framework. The Sociological Review, 46(3), 505-535. https://doi.org/10.1111/1467954X.00129

Anthias, Floya (2009). Translocational Belonging, Identity and Generation: Questions and Problems in Migration and Ethnic Studies. Finnish Journal of Ethnicity and Migration, 4(1), 6-15.

Anzaldúa, Gloria, Norma Cantú, and Aída Hurtado (2012). Borderlands / La Frontera: The New Mestiza (4th ed.). Aunt Lute Books.

Bagri, Neha Thirani (2017, January 12). New Research Confirms the 'Sexuality Pay Gap' is Real. Quartz. Retrieved from https://qz.com/881303/eight-million-americans-areaffected-by-a-pay-gap-that-no-one-talks-about/

Bailey, Alison (2009). On Intersectionality, Empathy, And Feminist Solidarity: A Reply to Naomi Zack. Journal for Peace and Justice Studies, 19(1), 14-36. https://doi.org/10.5840/ peacejustice200919116

Barvosa, Edwina (2008). Wealth of Selves: Multiple Identities, Mestiza Consciousness, and the Subject of Politics. Texas A\&M University Press.

Bettcher, Talia Mae (2017). Trans Feminism: Recent Philosophical Developments. Philosophy Compass, 12(11), e12438. https://doi.org/10.1111/phc3.12438

Bilge, Sirma (2013). Intersectionality Undone: Saving Intersectionality from Feminist Intersectionality Studies. Du Bois Review: Social Science Research on Race, 10(2), 405-424. https://doi.org/10.1017/S1742058X13000283

Brah, Avtar and Ann Phoenix (2013). Ain't I A Woman? Revisiting Intersectionality. Journal of International Women's Studies, 5(3), 75-86.

Branco, Carla, Miguel R. Ramos, and Miles Hewstone (2019). The Association of GroupBased Discrimination with Health and Well-Being: A Comparison of Ableism with Other "Isms". Journal of Social Issues, 75(3), 814-846. https://doi.org/10.1111/josi.12340

Brannon, Tiffany N, Gerald D Higginbotham, and Kyshia Henderson (2017). Class Advantages and Disadvantages Are Not So Black and White: Intersectionality Impacts Rank and Selves. Current Opinion in Psychology, 18, 117-122. https://doi.org/10.1016/j. copsyc.2017.08.029

Bright, Liam Kofi, Daniel Malinsky, and Morgan Thompson (2016). Causally Interpreting Intersectionality Theory. Philosophy of Science, 83(1), 60-81. https://doi. org/10.1086/684173

Butler, Judith (1999). Gender Trouble: Feminism and the Subversion of Identity. Routledge.

Carastathis, Anna (2014a). Reinvigorating Intersectionality as a Provisional Concept. In Namita Goswami, Maeve O'Donovan, and Lisa Yount (Eds.), Why Race and Gender Still Matter: An Intersectional Approach (59-70). Pickering \& Chatto.

Carastathis, Anna (2014b). The Concept of Intersectionality in Feminist Theory. Philosophy Compass, 9(5), 304-314. https://doi.org/10.1111/phc3.12129

Carpenter, Morgan (2014, August). Intersex: Intersectionality, Epistemic Injustice and Structural Violence. Presented at the The Mental Health Services conference, Perth, Australia. Retrieved from http://morgancarpenter.com/wp-content/uploads/2015/08/MNCintersectionalities-epistemic-structural.pdf

Cat, Jordi (2017). The Unity of Science. In Edward N. Zalta (Ed.), The Stanford Encyclopedia of Philosophy (Fall 2017 ed.). Retrieved from https://plato.stanford.edu/archives/ fall2017/entries/scientific-unity/

Chetty, Raj, Nathaniel Hendren, Maggie Jones, and Sonya Porter (2018). Race and Economic Opportunity in the United States: An Intergenerational Perspective (No. w24441). https://doi.org/10.3386/w24441 
Cho, Sumi (2013). Post-Intersectionality: The Curious Reception of Intersectionality in Legal Scholarship. Du Bois Review: Social Science Research on Race, 10(2), 385-404. https://doi.org/10.1017/S1742058X13000362

Cho, Sumi, Kimberlé Williams Crenshaw, and Leslie McCall (2013). Toward a Field of Intersectionality Studies: Theory, Applications, and Praxis. Signs, 38(4), 785-810. https://doi.org/10.1086/669608

Clarke, Averil Y. and Leslie McCall (2013). Intersectionality and Social Explanation in Social Science Research. Du Bois Review: Social Science Research on Race, 10(2), 349-363. https://doi.org/10.1017/S1742058X13000325

Cohen, Cathy J. (1997). Punks, Bulldaggers, and Welfare Queens: The Radical Potential of Queer Politics? GLQ: A Journal of Lesbian and Gay Studies, 3(4), 437-465. https://doi. org/10.1215/10642684-3-4-437

Cole, Elizabeth R. (2009). Intersectionality and Research in Psychology. American Psychologist, 64(3), 170-18o. https://doi.org/10.1037/a0014564

Cole, Elizabeth R. and Zakiya T. Luna (2010). Making Coalitions Work: Solidarity across Difference within US Feminism. Feminist Studies, 36(1), 71-98.

Collins, Patricia Hill (1990). Black Feminist Thought: Knowledge, Consciousness, and the Politics of Empowerment. Routledge.

Collins, Patricia Hill (2003). Some Group Matters: Intersectionality, Situated Standpoints, and Black Feminist Thought. In Tommy L. Lott and John P. Pittman (Eds.), A Companion to African-American Philosophy (205-229). https://doi.org/10.1002/9780470751640. ch12

Collins, Patricia Hill (2015). Intersectionality's Definitional Dilemmas. Annual Review of Sociology, 41(1), 1-20. https://doi.org/10.1146/annurev-soc-073014-112142

Collins, Patricia Hill and Sirma Bilge (2016). Intersectionality. John Wiley \& Sons.

Combahee River Collective (1977). A Black Feminist Statement. In Barbara Smith (Ed.), Home Girls: A Black Feminist Anthology (264-274). Rutgers University Press.

Cooper, Anna J. (2017). The Status of Woman in America. In By a Black Woman of the South: A Voice from the South (73-82). Retrieved from https://www.jstor.org/stable/10.5149/9781469633329_cooper.6

Cortina, Lilia M., Dana Kabat-Farr, Emily A. Leskinen, Marisela Huerta, and Vicki J. Magley (2013). Selective Incivility as Modern Discrimination in Organizations: Evidence and Impact. Journal of Management, 39(6), 1579-1605. https://doi. org/10.1177/0149206311418835

Cortland, Clarissa I., Maureen A. Craig, Jenessa R. Shapiro, Jennifer A. Richeson, Rebecca Neel, and Noah J. Goldstein (2017). Solidarity through Shared Disadvantage: Highlighting Shared Experiences of Discrimination Improves Relations between Stigmatized Groups. Journal of Personality and Social Psychology, 113(4), 547-567. https://doi. org/10.1037/pspi0000100

Crasnow, Sharon, Alison Wylie, Wenda K. Bauchspies, and Elizabeth Potter (2018). Feminist Perspectives on Science. In Edward N. Zalta (Ed.), The Stanford Encyclopedia of Philosophy (Spring 2018 ed.). Retrieved from https://plato.stanford.edu/archives/ spr2018/entries/feminist-science/

Crenshaw, Kimberlé (1989). Demarginalizing the Intersection of Race and Sex: A Black Feminist Critique of Antidiscrimination Doctrine, Feminist Theory and Antiracist Politics. University of Chicago Legal Forum, 1989, 139-167. 
Crenshaw, Kimberlé (1991). Mapping the Margins: Intersectionality, Identity Politics, and Violence against Women of Color. Stanford Law Review, 43(6), 1241-1299. https:// doi.org/10.2307/1229039

Crenshaw, Kimberlé (2008). The Curious Resurrection of First Wave Feminism in the U.S. Elections: An Intersectional Critique of the Rhetoric of Solidarity and Betrayal. In Lena Gunnarsson (Ed.), GEXcel Work in Progress Report Volume III (27-38). Retrieved from http://www.diva-portal.org/smash/get/diva2:137683/FULLTEXT02. pdf\#page $=27$

Crenshaw, Kimberlé (2011). Postscript. In Maria Teresa Herrera Vivar, Helma Lutz, and Linda Supik (Eds.), Framing Intersectionality: Debates on a Multi-Faceted Concept in Gender Studies (221-234). Retrieved from https://www.taylorfrancis.com/ books/9781317133575

Crenshaw, Kimberlé (2015, September 24). Why Intersectionality Can't Wait. Washington Post. Retrieved from https://www.washingtonpost.com/news/in-theory/ wp/2015/09/24/why-intersectionality-cant-wait/

Davis, Angela Y. (1983). Women, Race, E Class (1st Vintage Books ed.). Vintage.

Davis, Kathy (2008). Intersectionality as Buzzword: A Sociology of Science Perspective on What Makes a Feminist Theory Successful. Feminist Theory, 9(1), 67-85. https:// doi.org/10.1177/1464700108086364

Degraffenreid v. General Motors Assembly Div., Etc., 413 F. Supp. 142 (Dist. Court 1976).

Dhamoon, Rita Kaur (2011). Considerations on Mainstreaming Intersectionality. Political Research Quarterly, 64(1), 230-243. https://doi.org/10.1177/1065912910379227

Doetsch-Kidder, Sharon (2013). Social Change and Intersectional Activism: The Spirit of Social Movement. Palgrave Macmillan. https://doi.org/10.1057/9781137100979

Dotson, Kristie (2014). Conceptualizing Epistemic Oppression. Social Epistemology, 28(2), 115-138. https://doi.org/10.1080/02691728.2013.782585

Drury, M. O'C. (1996). The Danger of Words: And Writings on Wittgenstein (D. Berman, M. Fitzgerald, and J. Hayes, Eds.). Thoemmes Pr.

Du Bois, W. E. B. (1920). Darkwater: Voices from within the Veil. Harcourt, Brace and Howe. Retrieved from http://archive.org/details/darkwatervoicesf00duborich

Dubrow, Joshua (2013). Why Should We Account for Intersectionality in Quantitative Analysis of Survey Data? In Vera Kallenberg, Jennifer Meyer, and Johanna M. Müller (Eds.), Intersectionality und Kritik: Neue Perspektiven für alte Fragen (161-177). https:// doi.org/10.1007/978-3-531-93168-5_8

Ehrenreich, Nancy (2002). Subordination and Symbiosis: Mechanisms of Mutual Support between Subordinating Systems. University of Missouri-Kansas City Law Review, $71,251-324$.

Else-Quest, Nicole M. and Janet Shibley Hyde (2016). Intersectionality in Quantitative Psychological Research: II. Methods and Techniques. Psychology of Women Quarterly, 40(3), 319-336. https://doi.org/10.1177/0361684316647953

Frederick, Angela and Dara Shifrer (2018). Race and Disability: From Analogy to Intersectionality. Sociology of Race and Ethnicity, 2332649218783480. https://doi. org/10.1177/2332649218783480

Fricker, Miranda (2007). Epistemic Injustice: Power and the Ethics of Knowing. Oxford University Press. https://doi.org/10.1093/acprof:oso/9780198237907.001.0001

Galupo, M. Paz, Edward Lomash, and Renae C. Mitchell (2017). "All of My Lovers Fit Into This Scale": Sexual Minority Individuals' Responses to Two Novel Measures of 
Sexual Orientation. Journal of Homosexuality, 64(2), 145-165. https://doi.org/10.1080/ 00918369.2016.1174027

Garry, Ann (2011). Intersectionality, Metaphors, and the Multiplicity of Gender. Hypatia, 26(4), 826-85o. https://doi.org/10.1111/j.1527-2001.2011.01194.x

Grasswick, Heidi (2018). Feminist Social Epistemology. In Edward N. Zalta (Ed.), The Stanford Encyclopedia of Philosophy (Fall 2018 ed.). Retrieved from https://plato.stanford.edu/archives/fall2018/entries/feminist-social-epistemology/

Greenman, Emily and Yu Xie (2008). Double Jeopardy? The Interaction of Gender and Race on Earnings in the United States. Social Forces, 86(3), 1217-1244. https://doi. org/10.1353/sof.0.0008

Guyer, Paul (1990). Reason and Reflective Judgment: Kant on the Significance of Systematicity. Nô̂s, 24(1), 17-43. https://doi.org/10.2307/2215611

Hancock, Ange-Marie (2007a). Intersectionality as a Normative and Empirical Paradigm. Politics \& Gender, 3(02). https://doi.org/10.1017/S1743923X07000062

Hancock, Ange-Marie (2007b). When Multiplication Doesn't Equal Quick Addition: Examining Intersectionality as a Research Paradigm. Perspectives on Politics, 5(1), 63-79. https://doi.org/10.1017/S1537592707070065

Hancock, Ange-Marie (2013). Empirical Intersectionality: A Tale of Two Approaches. UC Irvine Law Review, 3(2), 259.

Hancock, Ange-Marie (2016). Intersectionality: An Intellectual History (1st ed.). Oxford University Press. https://doi.org/10.1093/acprof:oso/9780199370368.003.0001

Harkness, Sarah K. (2016). Discrimination in Lending Markets: Status and the Intersections of Gender and Race. Social Psychology Quarterly, 79(1), 81-93. https://doi. org/10.1177/0190272515623459

Haslanger, Sally (2014). Race, Intersectionality, and Method: A Reply to Critics. Philosophical Studies, 171(1), 109-119. https://doi.org/10.1007/s11098-013-0244-1

hooks, bell (1984). Feminist Theory: From Margin to Center. Pluto Press.

Howansky, Kristina, Leigh S. Wilton, Danielle M. Young, Samantha Abrams, and Rebekah Clapham (2019). (Trans)gender Stereotypes and the Self: Content and Consequences of Gender Identity Stereotypes. Self and Identity. Advance online publication. https://doi.org/10.1080/15298868.2019.1617191

Hull, Akasha, Patricia Bell-Scott, and Barbara Smith (Eds.) (1993). But Some Of Us Are Brave: All the Women Are White, All the Blacks Are Men: Black Women's Studies. The Feminist Press at CUNY.

Johnson, Kerri L., Jonathan B. Freeman, and Kristin Pauker (2012). Race is Gendered: How Covarying Phenotypes and Stereotypes Bias Sex Categorization. Journal of Personality and Social Psychology, 102(1), 116-131. https://doi.org/10.1037/a0025335

Jordan-Young, Rebecca M. (2011). Brain Storm: The Flaws in the Science of Sex Differences. Harvard University Press. https://doi.org/10.2307/j.ctvjf9w21

Jordan-Zachery, Julia (2013). Now You See Me, Now You Don't: My Political Fight against the Invisibility/Erasure of Black Women in Intersectionality Research. Politics, Groups and Identities, I(1), 101-109. https://doi.org/10.1080/21565503.2012.760314

Kant, Immanuel (1996). The Metaphysics of Morals. In Mary J. Gregor (Ed.), Practical Philosophy (353-604). https://doi.org/10.1017/CBO9780511813306.013

Kant, Immanuel (1999). Critique of Pure Reason. Paul Guyer \& Allen W. Wood, Eds. Cambridge University Press. https://doi.org/10.1017/CBO9780511804649 
Kant, Immanuel (2006). Anthropology from a Pragmatic Point of View. R. B. Louden, Ed. Cambridge University Press.

Kim, C. and Y. Zhao (2014). Are Asian American Women Advantaged? Labor Market Performance of College Educated Female Workers. Social Forces, 93(2), 623-652. https://doi.org/10.1093/sf/sou076

King, Deborah K. (1988). Multiple Jeopardy, Multiple Consciousness: The Context of a Black Feminist Ideology. Signs, 14(1), 42-72. https://doi.org/10.1086/494491

Kinsey, Alfred C. (1998). Sexual Behavior in the Human Male. Indiana University Press.

Kitcher, Philip (1999). Unification as a Regulative Ideal. Perspectives on Science, 7(3), 337348. https://doi.org/10.1162/posc.1999.7.3.337

Klawitter, Marieka (2015). Meta-Analysis of the Effects of Sexual Orientation on Earnings. Industrial Relations: A Journal of Economy and Society, 54(1), 4-32. https://doi. org/10.1111/irel.12075

Kleingeld, Pauline (2007). Kant's Second Thoughts on Race. The Philosophical Quarterly, 57(229), 573-592. https://doi.org/10.1111/j.1467-9213.2007.498.x

Knapp, Gudrun-Axeli (2005). Race, Class, Gender: Reclaiming Baggage in Fast Travelling Theories. European Journal of Women's Studies, 12(3), 249-265. https://doi. org/10.1177/1350506805054267

Kuhn, Thomas S. (1996). The Structure of Scientific Revolutions (3rd ed). University of Chicago Press.

Livingston, Robert W., Ashleigh Shelby Rosette, and Ella F. Washington (2012). Can an Agentic Black Woman Get Ahead? The Impact of Race and Interpersonal Dominance on Perceptions of Female Leaders. Psychological Science, 23(4), 354-358. https:// doi.org/10.1177/0956797611428079

Lorde, Audre (2012). Sister Outsider: Essays and Speeches. Crossing Press.

Lugones, María (2007). Heterosexualism and the Colonial / Modern Gender System. Hypatia, 22(1), 186-209. https://doi.org/10.1353/hyp.2006.0067

Lugones, María (2010). Toward a Decolonial Feminism. Hypatia, 25(4), 742-759. https:// doi.org/10.1111/j.1527-2001.2010.01137.x

MacKinnon, Catharine A. (2013). Intersectionality as Method: A Note. Signs, 38(4), 10191030. https://doi.org/10.1086/669570

Marwah, Inder S. (2013). What Nature Makes of Her: Kant's Gendered Metaphysics. Hypatia, 28(3), 551-567. https://doi.org/10.1111/j.1527-2001.2012.01277.x

Matsuda, Mari J. (1991). Beside My Sister, Facing the Enemy: Legal Theory out of Coalition. Stanford Law Review, 43(6), 1183-1192. https://doi.org/10.2307/1229035

May, Vivian M. (2015). Pursuing Intersectionality, Unsettling Dominant Imaginaries (1st ed.). Routledge.

McCall, Leslie (2005). The Complexity of Intersectionality. Signs, 30(3), 1771-180o. https:// doi.org/10.1086/426800

Mills, Charles W. (2017). Kant's Untermenschen. In Black Rights/White Wrongs: The Critique of Racial Liberalism (169-193). https://doi.org/10.1093/acprof:o so/9780190245412.001.0001

Misra, Joya and Marta Murray-Close (2014). The Gender Wage Gap in the United States and Cross Nationally. Sociology Compass, 8(11), 1281-1295. https://doi.org/10.1111/ soc4.12213

Moraga, Cherríe (2015). La Güera. In Cherríe Moraga and Gloria Anzaldúa (Eds.), This 
Bridge Called My Back: Writings by Radical Women of Color (4th ed., 22-29). SUNY Press.

Moraga, Cherríe, and Gloria Anzaldúa (Eds.) (2015). This Bridge Called My Back: Writings by Radical Women of Color (4th ed.). SUNY Press.

Movement for Black Lives (n.d.). Platform. Retrieved 6 January 2019, from The Movement for Black Lives website: https://policy.m4bl.org/platform/

Narayan, Uma (1997). Dislocating Cultures (1st ed.). Routledge.

Nash, Jennifer C. (2008). re-thinking intersectionality. Feminist Review, 89(1), 1-15. https:// doi.org/10.1057/fr.2008.4

Nash, Jennifer C. (2017). Intersectionality and Its Discontents. American Quarterly, 69(1), 117-129. https://doi.org/10.1353/aq.2017.0006

Nawyn, Stephanie J. and Linda Gjokaj (2014). The Magnifying Effect of Privilege: Earnings Inequalities at the Intersection of Gender, Race, and Nativity. Feminist Formations, 26(2), 85-106. https://doi.org/10.1353/ff.2014.0015

Nickles, Thomas (2017). Scientific Revolutions. In Edward N. Zalta (Ed.), The Stanford Encyclopedia of Philosophy (Winter 2017 ed.). Retrieved from https://plato.stanford. edu/archives/win2017/entries/scientific-revolutions/

Parrott, Heather Macpherson (2014). Housework, Children, and Women's Wages across Racial-Ethnic groups. Social Science Research, 46, 72-84. https://doi.org/10.1016/j.ssresearch.2014.02.004

Pedulla, D. S. (2014). The Positive Consequences of Negative Stereotypes: Race, Sexual Orientation, and the Job Application Process. Social Psychology Quarterly, 77(1), 7594. https://doi.org/10.1177/0190272513506229

Petsko, Christopher D. and Galen V. Bodenhausen (2019). Racial Stereotyping of Gay Men: Can a Minority Sexual Orientation Erase Race? Journal of Experimental Social Psychology, 83, 37-54. https://doi.org/10.1016/j.jesp.2019.03.002

Phoenix, Ann and Pamela Pattynama (2006). Intersectionality. European Journal of Women's Studies, 13(3), 187-192. https://doi.org/10.1177/1350506806065751

Protected Group (2019). In Wikipedia. Retrieved from https://en.wikipedia.org/w/index. php?title=Protected_group\&oldid=880784615

Puar, Jasbir K. (2007). Terrorist Assemblages: Homonationalism in Queer Times. Duke University Press. https://doi.org/10.1215/9780822390442

Puar, Jasbir K. (2012). 'I Would Rather Be a Cyborg than a Goddess': BecomingIntersectional in Assemblage Theory. PhiloSOPHIA, 2(1), 49-66.

Purdie-Vaughns, Valerie and Richard P. Eibach (2008). Intersectional Invisibility: The Distinctive Advantages and Disadvantages of Multiple Subordinate-Group Identities. Sex Roles, 59(5-6), 377-391. https://doi.org/10.1007/s11199-008-9424-4

Rosette, Ashleigh Shelby, Christy Zhou Koval, Anyi Ma, and Robert Livingston (2016). Race Matters for Women Leaders: Intersectional Effects on Agentic Deficiencies and Penalties. The Leadership Quarterly, 27(3), 429-445. https://doi.org/10.1016/j. leaqua.2016.01.008

Rumsey, Jean P. (2007). Re-Visions of Agency in Kant's Moral Theory. In Robin Schott (Ed.), Feminist Interpretations of Immanuel Kant (1st ed., 125-144). Penn State University Press.

Schott, Robin (Ed.) (2007). Feminist Interpretations of Immanuel Kant (1st ed.). Penn State University Press. 
Schroer, Jeanine Weekes (2015). Giving Them Something They Can Feel: On the Strategy of Scientizing the Phenomenology of Race and Racism. Knowledge Cultures, 3(1), 91-110.

Schug, Joanna, Nicholas P. Alt, Philip S. Lu, Monika Gosin, and Jennifer L. Fay (2017). Gendered Race in Mass Media: Invisibility of Asian Men and Black Women in popular Magazines. Psychology of Popular Media Culture, 6(3), 222-236. https://doi. org/10.1037/ppm0000096

Sesko, Amanda K. and Monica Biernat (2010). Prototypes of Race and Gender: The Invisibility of Black women. Journal of Experimental Social Psychology, 46(2), 356-36o. https://doi.org/10.1016/j.jesp.2009.10.016

Settles, Isis H. (2006). Use of an Intersectional Framework to Understand Black Women's Racial and Gender Identities. Sex Roles, 54(9-10), 589-601. https://doi.org/10.1007/ s11199-006-9029-8

Shields, Stephanie A. (2008). Gender: An Intersectionality Perspective. Sex Roles, 59(5-6), 301-311. https://doi.org/10.1007/s11199-008-9501-8

Spelman, Elizabeth V. (1988). Woman: The One and the Many. In Inessential Woman: Problems of Exclusion in Feminist Thought (133-159). Beacon Press.

Sweetman, Joseph (2018). When Similarities Are More Important than Differences: "Politically Black" Union Members' Experiences of Racism and Participation in Union Leadership. Journal of Social Issues, 74(2), 244-264. https://doi.org/10.1111/josi.12267

Táíwò, Olúfemi (2018). The Man-Not and the Dilemmas of Intersectionality. APA Newsletter on Philosophy and the Black Experience, 17(2), 6-10.

Terriquez, Veronica (2015). Intersectional Mobilization, Social Movement Spillover, and Queer Youth Leadership in the Immigrant Rights Movement: Table 1. Social Problems, 62(3), 343-362. https://doi.org/10.1093/socpro/spv010

Tine, Michele and Rebecca Gotlieb (2013). Gender-, Race-, and Income-Based Stereotype Threat: The Effects of Multiple Stigmatized Aspects of Identity on Math Performance and Working Memory Function. Social Psychology of Education, 16(3), 353-376. https://doi.org/10.1007/s11218-013-9224-8

U.S. Equal Employment Opportunity Commission (n.d.). Types of Discrimination. Retrieved 9 August 2017, from https://www.eeoc.gov/laws/types/

van Amsterdam, Noortje (2013). Big Fat Inequalities, Thin Privilege: An Intersectional Perspective on 'Body Size'. European Journal of Women's Studies, 20(2), 155-169. https://doi.org/10.1177/1350506812456461

Warner, Leah R., Isis H. Settles, and Stephanie A. Shields (2016). Invited Reflection: Intersectionality as an Epistemological Challenge to Psychology. Psychology of Women Quarterly, 40(2), 171-176. https://doi.org/10.1177/0361684316641384

Williams, Garrath (2018). Kant's Account of Reason. In Edward N. Zalta (Ed.), The Stanford Encyclopedia of Philosophy (Summer 2018 ed.). Retrieved from https://plato.stanford.edu/archives/sum2018/entries/kant-reason/

Wilson, John Paul, Jessica D. Remedios, and Nicholas O. Rule (2017). Interactive Effects of Obvious and Ambiguous Social Categories on Perceptions of Leadership: When Double-Minority Status May Be Beneficial. Personality and Social Psychology Bulletin, 43(6), 888-90o. https://doi.org/10.1177/0146167217702373

Young, Iris Marion (1994). Gender as Seriality: Thinking about Women as a Social Collective. Signs, 19(3), 713-738. https://doi.org/10.1086/494918

Yuval-Davis, Nira (2006). Intersectionality and Feminist Politics. European Journal of Women's Studies, 13(3), 193-209. https://doi.org/10.1177/1350506806065752 